\title{
Abridged version of the AWMF guideline for the medical clinical diagnostics of indoor mould exposure
}

\author{
S2K Guideline of the German Society of Hygiene, Environmental Medicine and \\ Preventive Medicine (GHUP) in collaboration with the German Association of \\ Allergists (AeDA), the German Society of Dermatology (DDG), the German \\ Society for Allergology and Clinical Immunology (DGAKI), the German Society \\ for Occupational and Environmental Medicine (DGAUM), the German Society \\ for Hospital Hygiene (DGKH), the German Society for Pneumology and \\ Respiratory Medicine (DGP), the German Mycological Society (DMykG), the \\ Society for Pediatric Allergology and Environmental Medicine (GPA), the \\ German Federal Association of Pediatric Pneumology (BAPP), and the Austrian \\ Society for Medical Mycology (ÖGMM)
}

Gerhard A. Wiesmüller · Birger Heinzow · Ute Aurbach · Karl-Christian Bergmann · Albrecht Bufe · Walter Buzina • Oliver A. Cornely · Steffen Engelhart · Guido Fischer · Thomas Gabrio · Werner Heinz - Caroline E. W. Herr · Jörg Kleine-Tebbe · Ludger Klimek · Martin Köberle · Herbert Lichtnecker · Thomas Lob-Corzilius · Rolf Merget • Norbert Mülleneisen · Dennis Nowak - Uta Rabe · Monika Raulf · Hans Peter Seidl · Jens-Oliver Steiß • Regine Szewszyk · Peter Thomas · Kerttu Valtanen · Julia Hurraß

Published online: 28 February 2017

(C) The Author(s) 2017. This article is available at SpringerLink with Open Access.

\begin{abstract}
This article is an abridged version of the AWMF mould guideline "Medical clinical diagnostics of indoor mould exposure" presented in April 2016 by the German Society of Hygiene, Environmental Medicine and Preventive Medicine (Gesellschaft für Hygiene, Umweltmedizin und Präventivmedizin, GHUP), in collaboration with the above-mentioned scientific medical societies, German and Austrian societies, medical associations and experts. Indoor mould growth is a potential health risk, even if a quantitative and/or causal relationship between the occurrence of individual mould species and health problems has yet to be established. Apart from allergic bronchopulmonary aspergillosis (ABPA) and mould-caused mycoses, only sufficient evidence for an association between moisture/mould damage and the following health effects has been established: allergic respiratory disease, asthma (manifestation, progression and exacerbation), allergic rhinitis, hypersensitivity pneumonitis (extrinsic allergic alveolitis), and increased likelihood of respiratory infections/ bronchitis. In this context the sensitizing poten-
\end{abstract}

tial of moulds is obviously low compared to other environmental allergens. Recent studies show a comparatively low sensitizing prevalence of $3-10 \%$ in the general population across Europe. Limited or suspected evidence for an association exist with respect to mucous membrane irritation and atopic eczema (manifestation, progression and exacerbation). Inadequate or insufficient evidence for an association exist for chronic obstructive pulmonary disease, acute idiopathic pulmonary hemorrhage in children, rheumatism/arthritis, sarcoidosis and cancer. The risk of infection posed by moulds regularly occurring indoors is low for healthy persons; most species are in risk group 1 and a few in risk group 2 (Aspergillus fumigatus, A. flavus) of the German Biological Agents Act (Biostoffuerordnung). Only moulds that are potentially able to form toxins can be triggers of toxic reactions. Whether or not toxin formation occurs in individual cases is determined by environmental and growth conditions, above all the substrate. In the case of indoor moisture/mould damage, everyone can be affected by odour effects and/or mood disorders. 
However, this is not a health hazard. Predisposing factors for odour effects can include genetic and hormonal influences, imprinting, context and adaptation effects. Predisposing factors for mood disorders may include environmental concerns, anxiety, condition, and attribution, as well as various diseases. Risk groups to be protected particularly with regard to an infection risk are persons on immunosuppression according to the classification of the German Commission for Hospital Hygiene and Infection Prevention (Kommission für Krankenhaushygiene und Infektion-

\section{G. A. Wiesmüller}

Institute for Occupational Medicine and Social Medicine,

University Hospital, Medical Faculty, RWTH Aachen

University, Aachen, Germany

G. A. Wiesmüller $(\square) \cdot$ J. Hurraß

Department of Infection Control and Environmental

Hygiene, Cologne Health Authority, Neumarkt

15-21, 50667 Cologne, Germany

gerhard.wiesmueller@stadt-koeln.de

\section{B. Heinzow}

Formerly: Regional Social Security Authorities (LAsD) for Schleswig-Holstein, Kiel, Germany

\section{U. Aurbach}

Department of Microbiology and Mycology, Dr. Wisplinghoff Laboratory, Cologne, Germany

\section{K.-C. Bergmann}

Allergy-Centre-Charité, Charité-Universitätsmedizin, Berlin, Germany

\section{A. Bufe}

Experimental Pneumology, Ruhr University, Bochum, Germany

W. Buzina

Institute for Hygiene, Microbiology and Environmental Medicine, Medical University of Graz, Graz, Austria

\section{O. A. Cornely}

Department I for Internal Medicine and Cologne Excellence Cluster on Cellular Stress Responses in Aging-Associated Diseases (CECAD), University of Cologne, Cologne, Germany

S. Engelhart

Institute for Hygiene and Public Health, Bonn University Hospital, Bonn, Germany

G. Fischer

Baden-Württemberg Regional Health Authorities at the Regional Council Stuttgart, Stuttgart, Germany

T. Gabrio

Formerly: Baden-Württemberg Regional Health Authorities at the Regional Council in Stuttgart, Stuttgart, Germany

W. Heinz

Medical Clinic and Outpatient Clinic II with Special Focus on Infectiology, Würzburg University Hospital, Würzburg, Germany

\section{E. W. Herr}

Bavarian Office for Health and Food Safety, Munich, Germany

Adj. Prof. "Hygiene and Environmental Medicine", Ludwig-Maximilian University, Munich, Germany sprävention, KRINKO) at the Robert Koch- Institute (RKI) and persons with cystic fibrosis (mucoviscidosis); with regard to an allergic risk, persons with cystic fibrosis (mucoviscidosis) and patients with bronchial asthma should be protected.

The rational diagnostics include the medical history, physical examination, and conventional allergy diagnostics including provocation tests if necessary; sometimes cellular test systems are indicated. In the case of mould infections the reader is referred to the AWMF guideline "Diagnosis and Therapy of Invasive Aspergillus Infections”. With regard to myco-

\section{J. Kleine-Tebbe}

Westend Allergy and Asthma Centre, Berlin, Germany

\section{Klimek}

Wiesbaden Centre for Rhinology and Allergology,

Wiesbaden, Germany

\section{Köberle}

Clinic and Outpatient Clinic for Dermatology and

Allergology am Biederstein, Technical University of Munich, Munich, Germany

\section{H. Lichtnecker}

Medical Institute for Environmental and Occupational Medicine MIU GmbH, Erkrath, Germany

T. Lob-Corzilius

Christian Children’s Hospital, Osnabrück, Germany

\section{R. Merget · M. Raulf}

Institute for Prevention and Occupational Medicine of the German Social Accident Insurance, Institute of the Ruhr University Bochum (IPA), Bochum, Germany

N. Mülleneisen

Leverkusen Asthma and Allergy Centre, Leverkusen, Germany

D. Nowak

Institute and Outpatient Clinic for Occupational, Social, and Environmental Medicine, Member of the German Centre for Lung Research, Munich University Hospital, Munich, Germany

U. Rabe

Centre for Allergology and Asthma, Johanniter Hospital im Fläming Treuenbrietzen GmbH, Treuenbrietzen, Germany

H. P. Seidl

Formerly: Chair of Microbiology and Clinic and Outpatient Clinic for Dermatology and Allergology am Biederstein, Technical University of Munich, Munich, Germany

J.-O. Steiß

Centre for Pediatric and Adolescent Medicine, University Hospital Gießen and Marburg GmbH, Gießen, Germany

Specialist Practice for Allergology and Pediatric Pneumology, Fulda, Germany

R. Szewszyk · K. Valtanen

FG (specialist field) II 1.4 Microbiological Risks, Federal Environmental Agency, Berlin, Germany

\section{P. Thomas}

Department and Outpatient Clinic for Dermatology and Allergology, Ludwig-Maximilian University, Munich, Germany 
toxins, there are currently no useful and validated test procedures for clinical diagnostics. From a preventive medicine standpoint it is important that indoor mould infestation in relevant dimension cannot be tolerated for precautionary reasons. With regard to evaluating the extent of damage and selecting a remedial procedure, the reader is referred to the revised version of the mould guideline issued by the German Federal Environment Agency (Umweltbundesamt, UBA).

Keywords Mould · Health risk · Indoor - Diagnostics · Guideline

\section{Introduction}

In April 2016, the German Society of Hygiene, Environmental Medicine and Preventive Medicine (Gesellschaft für Hygiene, Umweltmedizin und Präventivmedizin, GHUP), in collaboration with the abovementioned scientific medical societies, German and Austrian societies, medical associations and experts, presented the AWMF mould guideline "Medical clinical diagnostics of indoor mould exposure" [1].

This article is an abridged version of this AWMF guideline. More detailed information on all the content presented in this abridged version can be found in the AWMF mould guideline. Whenever reference is made below to the full version of the guideline, "AWMF mould guideline" is used.

The core messages of the AWMF mould guideline, which in turn contain core recommendations, are presented. The strength of recommendation is expressed using the following terms: strong recommendation: "shall"; recommendation: "should"; open recommendation: "may."

\section{Core messages of the AWMF mould guideline}

The problem of indoor mould exposure needs to be addressed in a more fact-based manner.

1. Relevant levels of indoor mould infestation must not be tolerated for precautionary reasons. For the assessment of damage extent, the reader is referred to the "Guideline on the prevention, investigation, evaluation and remediation of indoor mould growth" (mould guideline) issued by the German Federal Environment Agency (Umweltbundesamt, UBA) [2]. A revised version of the UBA mould guideline is expected in 2017.

2. The most important measures in indoor mould exposure include cause identification and appropriate remediation (see mould remediation guides $[3,5])$.

3. Medically indicated indoor mould measurements are rarely helpful. In general, both quantitative and qualitative determinations of the mould species can be dispensed with in the case of visible mould infestation. Instead, identifying the cause of infestation is far more important, followed by the elimination of infestation and its primary causes.

4. Mould exposure can generally lead to mucous membrane irritation (MMI), odour effects and mood disorders.

5. Specific clinical pictures seen in mould exposure are pertinent to allergies and fungal infections (mycosis).

6. It is the physician's duty to objectify suspected links between indoor moisture damage/mould and gastrointestinal or renal disease, reproductive disorders, teratogenicity or cancer.

7. Risk groups warranting particular protection include:

a) individuals on immunosuppression according to the classification of the German Commission for Hospital Hygiene and Infection Prevention (Kommission für Krankenhaushygiene und Infektionsprävention, KRINKO) at the Robert KochInstitute (RKI) [11],

b) individuals with cystic fibrosis (mucoviscidosis),

c) individuals with bronchial asthma.

8. The risk for developing asthma ("allergic march") is increased in:

a) patients with allergic rhinoconjunctivitis,

b) patients with allergic rhinosinusitis,

c) atopic patients.

9. It is likely that all moulds are capable of causing sensitization and allergies. Their allergenic potential is considered lower compared with other environmental allergens $[12,13]$.

10. As polysensitized individuals, atopics (those susceptible to hypersensitivity reactions, such as allergic rhinitis (hay fever), allergic asthma, and atopic dermatitis on contact with environmental substances) often also exhibit IgE antibodies to moulds; however, this does not necessarily indicate relevant disease.

11. The core elements of allergy diagnostics include medical history, skin testing (skin prick test), in vitro serological examination of specific IgE antibodies in type I sensitization or specific IgG antibodies in hypersensitivity pneumonitis (HP; extremely rare in non-occupationally related indoor exposure) and provocation testing.

12. The identification of specific IgE means that a specific sensitization to relevant allergens is present. However, this cannot be equated to a clinically relevant allergy any more than a positive skin test reaction can be.

13. Negative in vitro and in vivo tests do not exclude sensitization or mould allergy.

14. The determination of specific IgG antibodies as part of the diagnostic work-up for immediate-type mould allergy (type I allergy) is of no diagnostic relevance and is therefore not recommended. 
15. Lymphocyte transformation testing (LTT) for moulds is not indicated as a diagnostic method [14].

16. Mould-related infections are rare and are most likely to occur via the inhalative route. In practice, Aspergillus fumigatus - the most important mycotic pathogen-is of the greatest relevance among the 460 moulds classified in risk groups 2 and 3 according the German Technical Rules for Biological Materials (Technische Regeln für Biologische Arbeitsstoffe, TRBA). Individuals with local or general immunodeficiency are by far those most frequently affected.

17. Core elements of the diagnostic work-up for mould infection include microbiological, immunological, molecular biological and radiological methods.

18. Mould-allergic individuals, as well as patients with diseases that weaken the immune system, should be provided with specialist patient information on the hazards of indoor mould exposure and the preventive steps that can be taken to minimize this exposure.

\section{Aim of the AWMF mould guideline}

The guideline is intended to close the existing gap in the rational and efficient medical diagnostics of indoor mould exposure. To date, only guidelines on building-related procedures in the case of moisture damage [2-6] and overview articles on associated diseases [7-10] have been available-however, no comprehensive, patient-related diagnostic procedure.

The AWMF guideline does not address workplacerelated diseases or specific workplace exposure, oral ingestion of moulds or mould components or yeastand dermatophyte-related diseases.

The scientific literature on moulds is extensive and largely published in English. In epidemiological studies, domestic exposure is often categorized using the terms "dampness and mould," i. e. no distinction is made between indoor moisture damage with or without mould infestation. This makes sense, since there is no health-related marker for quantitative mould exposure. "Mould" (or "mold" in American English) refers to "visible" mould structures, whereby "visible" also includes hidden mould infestation. The terms "dampness and mould" are translated in the AWMF mould guideline as "Feuchtigkeit und Schimmel". Further definitions can be found in the appendix to the AWMF mould guideline [1].

\section{Methodology}

A national network of experts belonging to the German Society for Hygiene, Environmental Medicine and Preventive Medicine (Gesellschaft für Hygiene, Umweltmedizin und Präventivmedizin, GHUP) was used to compile the AWMF mould guideline. The guideline builds on the statements of the Robert KochInstitute (RKI) Commission 'Methods and Quality Assurance in Environmental Medicine' (Kommission Methoden und Qualitätssicherung in der Umweltmedizin) [8], the World Health Organization (WHO) Guidelines for Indoor Air Quality: Dampness and Mould [9] and the scientific workshops held at the GHUP annual conferences (GHUP 2009-2012) on the subject of "mould and health" [15-18].

The present guideline has been drawn up in accordance with the methodological requirements for the development of diagnostics and treatment guidelines set out by the German Association of Scientific Medical Societies (Arbeitsgemeinschaft der wissenschaftlichen medizinischen Fachgesellschaften, AWMF) and represents an S2k guideline according to the AWMF three-level concept. The guideline is based on an extensive and systematic literature search; however, it does not formally meet the requirements for an S2k guideline, since there are no clinical studies available on this topic. Thus, it was not possible to assign evidence levels to recommendations.

A search in the Cochrane database with the terms "mold", "mould" and/or "dampness" produced three hits. Two reviews discussed specific immunotherapy in asthma and rhinitis, while one review analyzed the preventive effect on respiratory diseases of remediating damage caused by dampness and mould [19].

A conceptually graduated Medline search yielded 1949 references; screening was subsequently performed for limitation purposes. No reviews comprehensively or extensively addressing the topic of medical diagnostics in exposure to indoor mould and dampness were found, but rather only literature on individual topic areas. More details on these can be found in the AWMF mould guideline [1].

The search was conducted in German using Internet search machines (Google) and in English in the Medline (Medical Literature Analysis and Retrieval System Online) database.

Publications by the WHO [9], the Institute of Medicine (IOM, USA) [7], Palatya and Shum [20] as well as a recently published review by Mendell et al. [21] were used to make basic evaluations of the evidence of a link between mould exposure and defined clinical pictures.

Other guidelines were considered for individual topics, primarily diagnostics. These are listed in the relevant chapters of the AWMF mould guideline [1]. Other guidelines that were consulted include guidelines on the following: inhalant mould exposure; allergic rhinoconjunctivitis; rhinitis; rhinosinusitis; diagnostics and treatment of patients with asthma and bronchial asthma in children and adolescents; asthma treatment; urticaria; diagnosis of HP; allergic bronchopulmonary aspergillosis (ABPA) in cystic fibrosis; diagnostics and treatment of invasive Aspergillus infections; treatment of invasive aspergillosis; diag- 
nostics and treatment of invasive fungal infections; sarcoidosis in childhood and adolescence; management of early rheumatoid arthritis; diagnostics and treatment of adult patients with acute and chronic cough; in vitro allergy diagnostics; skin testing to diagnose immediate-type allergic reactions; the performance of nasal provocation tests; the performance of bronchial provocation tests; workplace-specific inhalation tests; (allergen-)specific immunotherapy in IgE-mediated allergic disease; and allergy prevention (see the AWMF mould guideline for a detailed list [1]).

The procedure used to draw up the guideline is presented in detail in the AWMF mould guideline [1].

\section{Incidence, exposure and health relevance of moulds}

\section{Definition and increased incidence of moulds}

Mould is a collective term for hyphae- and generally also spore-forming micro-fungi and does not represent a taxonomically defined fungal entity.

Moulds are a ubiquitous component of our biosphere and are found to varying degrees in outdoor air, in indoor areas, and in some workplaces.

Mould infestation (of materials) is considered to be present in building materials and fixtures that have been, or still are, covered (colonized) by mould. Unless already visible to the naked eye, determination is performed by means of microscopic identification of a network of hyphae and, by and large, fully developed conidia- or sporangia-bearers, irrespective of whether the moulds are still vital/active or have already died off. Other biomaterial, e. g. bacteria, may also be present besides moulds.

Mould contamination exceeds the general background levels of contamination of surfaces or materials (e.g. with fungal spores) via entry from outside (e.g. in house dust, airborne spores).

Mould growth refers to a process involving biological activity, i.e. it is associated with moisture and characterized by cell division, hyphae, mycelium and potentially spore formation, among other things.

Moisture damage is the visible, measurable or perceived effect of increased water content in indoor areas or structural components.

It makes sense from a practical point of view to summarize increased indoor exposure to moulds and other factors associated with increased moisture, such as yeasts, bacteria (Actinobacteria) and mites, as moisture/mould damage.

\section{Classification of moulds}

Fungi are eukaryotes with cell walls consisting of chitin and glucans.

The nomenclature of fungi is binomial, i.e. each organism bears the name of a genus and a species. However, renaming is relatively common in fungi due to continuous new findings and taxonomic classifications. This can lead to communication problems, e.g. when medical experts specify mould species found indoors (named differently in the new nomenclature in the meantime) in their report and include possible health-related problems in their appraisal. The MycoBank, an online database, provides current names, combinations and associated data, e.g. descriptions and illustrations (http://www.mycobank.org/).

In medical mycology, on the other hand, fungi are clinically classified into dermatophytes, yeasts and moulds, irrespective of taxonomy. Although the DHS system represents a practicable classification, it is misleading and, from a biological perspective, (taxonomically) incorrect, since moulds are not a taxonomical entity and most "yeasts" (yeast-like fungi) belong taxonomically to the Ascomycota, as do dermatophytes.

From a microbiological perspective, moulds should generally be given taxonomically as genus and species. If only the Latin genus name is given followed by sp. or spp., the particular species or group of species have not been further differentiated.

Another classification with a practical focus is made according to the different temperature and moisture requirements of the individual moulds [22, 23].

\section{Mycotoxins}

Mycotoxins are secondary metabolites produced by moulds, which, in low concentrations ( $\mu \mathrm{g} / \mathrm{kg}$ foods), can have toxic effects on various cell systems in vertebrates irrespective of the type of toxin and consumption habits. Numerous mould genera (e.g. Aspergillus, Penicillium, Fusarium, Alternaria, Stachybotrys) produce mycotoxins. Mycotoxin production depends on the species and environmental factors, such as substrate composition, moisture levels, $\mathrm{pH}$ value, light wavelength and nutrient competition [24]. As a general rule, mycotoxins produced by indoor-relevant moulds can be detected in extremely low concentrations (parts per trillion, ppt) in house dust [25], bioaerosols and building materials. Mycotoxins are not volatile and are found in the air bound to spores, cell fragments and other particles.

They are generally only found at levels relevant to health in foods and animal feed that have been colonized by mould.

The hitherto available data indicate that the levels of most airborne mycotoxins found indoors do not exhibit an acute toxic effect. Only the strongest toxic compounds, trichothecenes and gliotoxins, may be found at their effective concentrations as a result of mould-infested material indoors [26].

Clearly, the maximum expected levels of individual mycotoxins in situ (bioaerosols) do not alone explain these cytotoxic effects. It would appear that the synergistic effects of various mycotoxins, or mycotoxins with different cell components (e.g. glucanes, endo- 
toxins), are more likely to be responsible for this effect [8].

It is not yet possible to rule out the possibility that airborne concentrations of the compounds gliotoxin in Aspergillus fumigatus (only rarely relevant indoors) and the satratoxins in Stachybotrys chartarum reach a level that may be responsible for immunomodulatory effects and, thus, potentially promote susceptibility to infection or allergy development [27].

\section{Cell wall components and metabolites}

Besides mould spores and mycotoxins, other metabolites and cellular components, such as microbiological volatile organic compounds (MVOC), $\beta$-glucans, mannans and ergosterol, also play a role in mould exposure $[28,29]$, whereby MVOC are responsible for the characteristic odour of mould.

Ergosterol is a metabolite (sterol) of yeasts, moulds and edible mushrooms. It is produced as a membrane component in varying quantities.

Moisture damage is also accompanied by other microbiological components (e.g. found in house dust), such as the lysosomal enzyme N-acetyl- $\mathrm{B}-\mathrm{D}$ glucosaminidase and endotoxin (in bacteria) [30]. It is not yet known whether these markers (cell fragments, $ß$-glucan and ergosterol) correlate better with health effects than do culturable exposure parameters [31-37].

To date, 77 mould allergens (excluding dermatophytes and yeasts) have been described and officially recognized (www.allergen.org). The associated protein families differ significantly both biochemically and structurally from the allergen families in pollen, foods and animal dander [38].

\section{Health problems and diseases caused by moulds}

Epidemiological studies show, consistently and across studies, a relationship between indoor moisture damage and health effects, in particular: respiratory symptoms; eye, nose and throat irritation; blocked nose; wheezing; dry cough; and fatigue [39]. The AWMF mould guideline confines itself largely to clinical pictures rather than symptoms.

The relevant evidence of links between moisture/ mould damage and its various health effects is summarized in Table 1. In some cases, it is not possible to unequivocally establish causality between specific mould exposure and concrete health-related problems and clinical pictures.

Whether moulds pose a health risk largely depends on the disposition of the exposed individuals. Risk groups warranting particular protection include:

a) individuals on immunosuppression according to the Commission for Hospital Hygiene and Infection Prevention (Kommission für Krankenhaushygiene und Infektionsprävention, KRINKO) [11],
Table 1 Evidence of a link between indoor mould exposure or dampness and disorders (excluding mycoses) (modified from $[9,20,21,40,41])$

\section{Causal link \\ Insufficient evidence}

Sufficient evidence for an association:

Allergic airway diseases

Asthma (manifestation, progression, exacerbation)

Allergic rhinitis

Hypersensitivity pneumonitis (extrinsic allergic alveolitis)

Promotion of airway infections, bronchitis

Limited or suspected evidence for an association:

Mucous membrane irritation (MMI)

Atopic eczema (manifestation, progression, exacerbation)

Inadequate or insufficient evidence for an association:

Chronic obstructive pulmonary disease (COPD)

Acute idiopathic pulmonary haemorrhage in infants

Rheumatic disorders, arthritis

Sarcoidosis

Cancer

b) individuals with cystic fibrosis (mucoviscidosis),

c) individuals with bronchial asthma.

Ensuring that living conditions meet the highest possible standards of hygiene should be a fundamental requirement in all chronic diseases, including those with no, or insufficient, evidence of a link to moisture damage and/or mould exposure. If hygiene conditions or medical history suggest moisture damage and/or mould exposure, the primary causes need to be preventively eliminated, as with all moisture damage [42].

\section{Defined clinical pictures and health disorders}

No single mechanism or factor is able to explain the various health effects related to moisture damage and/or mould exposure [21, 43, 44]. Epidemiological findings point to both allergological and non-IgE-mediated immunological and toxic, immunomodulatory mechanisms. Moisture damage or mould growth can cause adverse effects in atopic as well as non-atopic individuals [45-48].

The sequence in which diseases are presented in the following is not intended to indicate any order of priority in relation to the topics addressed in the AWMF mould guideline.

\section{Allergic rhinitis}

As polysensitized individuals, atopics (i.e. persons with allergic asthma, allergic rhinitis, atopic dermatitis) often exhibit IgE antibodies against moulds.

Depending on the population, region and allergen spectrum investigated, the incidence of allergic rhinitis due to fungal allergens is given at rates ranging from $2.7-19 \%$ [49-51].

IgE-mediated rhinitis is most commonly elicited by allergens in moulds predominantly found in ambient air, in particular Alternaria alternata, and significantly less frequently Cladosporium herbarum, Botry- 
tis cinerea, Mucor sp., Penicillium sp. and Aspergillus sp. [49-51]. In epidemiological studies, indoor dampness and mould are consistently associated with allergic rhinitis [21, 52]. Monosensitization to indoor moulds, however, is likely to be rare [53].

\section{Non-invasive and invasive sinusitis}

Moulds can trigger chronic inflammation of the nasal and paranasal sinus mucosa via a variety of mechanisms [54, 55]. Among sensitizations to moulds in patients with chronic sinusitis, Alternaria, a typical mould in outdoor air, is the most prevalent [56].

A distinction is currently made between five forms of rhinosinusitis triggered by fungi:

a) acute invasive (including rhinocerebral mucormycosis),

b) chronic invasive,

c) granulomatous invasive,

d) non-invasive allergic fungal rhinosinusitis (AFRS) without and

e) with spherical mycetoma formation [54, 57].

The invasive forms are more prevalent in immunocompromised patients (AIDS, diabetes, chemotherapy etc.) and can cause death within a matter of weeks in the case of an acute (fulminant) course involving vascular invasion by hyphae. The chronic invasive form, on the other hand, follows a protracted course and, here again, immunosuppressed patients are predominantly affected. The granulomatous invasive form represents a type of fibrotic tumour formation, occurring primarily in Africa, Saudi Arabia and the Arab Gulf States.

Non-invasive AFRS was first described in conjunction with ABPA [58]. AFRS also resembles this bronchial disease in many respects. Dematiaceous hyphae (Bipolaris spicifera, Curvularia lunata) and Aspergillus species (e.g., Aspergillus fumigatus, A. niger and A. flavus) are most commonly found to be the trigger [59].

The presence of a thick, tenacious secretion and the typical histological finding of abundant eosinophils is clinically characteristic [60]. In the US, the diagnosis is considered confirmed if all the major criteria of the Bent \& Kuhn classification are met:

1. Type 1 allergy to fungal allergens confirmed by skin testing or in vitro testing.

2. Nasal polyposis.

3. Characteristic computed tomography findings.

4. The presence of eosinophilic mucin without invasion.

5. Positive fungal stain of sinus contents removed at surgery $[60,61]$.

Recent studies have shown that fungi can be found in the nose and paranasal sinuses of the vast majority of the population (including all CRS patients) [62].
Thus, alone the presence of fungi does not appear to be pathognomic - and hence diagnostically significant-but instead an expression of (a) a reduced immune response in invasive fungal diseases or (b) an altered, partially excessive immune response in AFRS to these ubiquitously occurring fungal spores.

Therefore, from a therapeutic perspective, treatment with topical and oral antifungal agents is only recommended in invasive forms, not however in AFRS, since double-blind placebo-controlled studies have not been able to show an effect for these agents [62], and a pathophysiological relationship to moulds cannot be assumed in the majority of CRS cases [63].

According to recent findings, severe, untreatable CRS is caused by (fungal, among other) biofilms. The precise pathomechanism has not yet been elucidated. It is likely that planktonic fungi are continually released by the biofilm; as part of this process, the mucosa is probably invaded by macrophages that phagocytose-but do not kill off-the fungal hyphae [64-67].

Fungal biofilms are made up of micro-fungal complexes that are capable of colonizing both biotic and abiotic surfaces. They cause circumvention of the immune system and reduce sensitivity to antifungal agents, while maintaining the ability to release planktonic micro-fungal hyphae. Numerous investigations using different detection methods have been able to demonstrate the presence of biofilms in the sinonasal mucosa of CRS patients [64-67]. The presence of biofilms was associated with poorer disease courses [64]. In patients requiring surgery, preoperative disease severity was greater in a patient group with proven biofilms in the sinonasal mucosa compared with a control group in whom no relevant biofilms were detected; however, the postoperative outcome was identical in both groups [66].

Confocal scanning laser microscopy with fluorescent in situ hybridization was deemed the "gold standard" in terms of biofilm detection methods [67]. This method should be combined with other microbiological investigations. Traditional culture techniques to detect and identify pathogens complement this diagnostic work-up [67]. Thus, biofilms are an interesting approach to explaining the persistence of moulds in the chronically inflamed sinus mucosa. The clinical significance of biofilms to disease course cannot be fully assessed as yet. It would be important in the future to develop suitable detection methods for routine clinical application.

\section{Allergic bronchial asthma}

As in allergic rhinitis, seasonal allergic bronchial asthma is primarily induced by moulds occurring at seasonally high levels in outdoor air (e.g. generally Alternaria, more rarely Cladosporium, Epicoccum, Fusarium), whereas indoor moulds (Aspergillus, Penicillium) cause perennial allergic bronchial asthma [8, 68]. The link between damp indoor environments and/or mould and the development of asthma, par- 
ticularly in children, can be considered as undisputed [21, 69-72].

The outdoor mould genus, Alternaria alternata (formerly A. tenuis), appears to be a particularly important mould in the context of asthma development and severity [73-77]. A temporal relationship between asthma symptoms and spore counts was seen particularly in cases of a high degree of sensitization, as well as in patients without concomitant grass pollen allergy. Other authors have emphasized the relevance in allergic asthma of Cladosporium sp., extremely high levels of which are found seasonally in outdoor air, as well as in cases of indoor infestation [78-83]. In rare cases, patients with seasonal asthma symptoms (June to September) may exhibit Alternaria sensitization without concomitant pollen sensitization [84].

Allergic bronchial asthma is often accompanied by other atopic diseases (atopic dermatitis, allergic rhinoconjunctivitis) [8, 85-89]. Monosensitization to indoor moulds is rare. Clinical investigations show that, in the case of mould, polyvalent sensitizations to other environmental allergens are often present [90]. Iversen and Dahl [91] also provide evidence that up to $95 \%$ of mould-allergic asthmatics were additionally sensitized to other inhalant allergens. The authors conclude that mould allergens, as weak allergens, only rarely induce monovalent allergies, or these generally only occur in patients with a high sensitization potential, and that genetic predisposition is more relevant in this sensitization process than is mould exposure in damp homes [91, 92].

\section{Atopic dermatitis (atopic eczema)}

As airborne allergens, mould allergens can likely trigger atopic dermatitis [86-88]. Epidemiological studies have yielded sufficient evidence to support a link between atopic dermatitis and moisture damage/mould [21].

\begin{tabular}{l|l}
$\begin{array}{l}\text { Table } 2 \\
\text { aspergillosis (ABPA) [117, 118, 120] (modified from Rosen- } \\
\text { berg et al. [115]) }\end{array}$ \\
$\begin{array}{l}\text { Diagnostic criteria for allergic bron- } \\
\text { chopulmonary aspergillosis (ABPA) }\end{array}$ & $\begin{array}{l}\text { If not all criteria are met, ABPA } \\
\text { is likely in the presence of the } \\
\text { following minimal criteria: }\end{array}$ \\
$\begin{array}{l}\text { Specific IgG antibodies (precipitins) } \\
\text { against Aspergillus sp }\end{array}$ & Asthma \\
\hline $\begin{array}{l}\text { Specific IgE antibodies against } \\
\text { Aspergillus sp }\end{array}$ & $\begin{array}{l}\text { Immediate-type cutaneous reaction } \\
\text { to Aspergillus sp }\end{array}$ \\
\hline $\begin{array}{l}\text { Total IgE (>1000 kU/I) } \\
\text { Detection of rAsp f } 4 \text { and rAsp f } 6\end{array}$ & $\begin{array}{l}\text { Transient pulmonary infiltrates } \\
\text { Elevated total IgE }\end{array}$ \\
\hline $\begin{array}{l}\text { Recurrent asthma } \\
\text { Recurrent transient pulmonary } \\
\text { infiltrates }\end{array}$ & $\begin{array}{l}\text { Specific IgG and IgE antibodies } \\
\text { against Aspergillus fumigatus }\end{array}$ \\
\hline $\begin{array}{l}\text { Immediate-type cutaneous reaction } \\
\text { to Aspergillus } \mathrm{sp}\end{array}$ & - \\
\hline $\begin{array}{l}\text { Blood eosinophilia, possibly sputum } \\
\text { eosinophilia }\end{array}$ & - \\
\hline \begin{tabular}{l} 
Central bronchiectasis \\
\hline
\end{tabular} & - \\
\hline
\end{tabular}

A variety of dermatological reactions to mould have been described, such as dryness, pruritus and skin rashes [93, 94]. Whether this represents an immunologically mediated form of skin reaction to indoor mould exposure is unclear [44]. However, occupational contact dermatitis in conjunction with mould exposure can also be a manifestation of immunologically mediated dermatitis in mould sensitization [95].

\section{Urticaria}

In rare cases, the ingestion of foods contaminated by mould components can trigger urticaria [86, 87]. Examples include mould components (such as enzymes) in beverages and bakery products or on dry fermented sausage/salami [96-98]. Airborne exposure as trigger of urticaria is unlikely [20] or extremely rare [99]. Occupational contact urticaria in conjunction with mould exposure may also be a manifestation of immunologically mediated dermatitis in mould sensitization [97].

\section{Hypersensitivity pneumonitis (HP)}

Clinical evidence has documented a link between HP (synonym: extrinsic allergic alveolitis [EAA]) in susceptible individuals and the occurrence of mould [7]. With a prevalence of between two and four cases per 100,000 inhabitants/year, HP is a rare allergy (type III, IV) to inhalant antigens [100, 101]. Indoor mould plays an important role in this rare disease. The antigens are found in dust and aerosols; possible microbially contaminated sources include, for instance, birds, feathers, hay, wood dust, air humidifiers, airconditioning systems, indoor fountains, aquariums and steam irons [102-104]. Most commonly, the antigens come from birds, moulds and actinomycetes [105]. Non-smokers are predominantly affected by HP. Sennekamp [106] has put together a comprehensive antigen catalogue. HP occurs primarily in the workplace [107] and belongs to the recognized occupational diseases (OD No. 4201). Non-workplacerelated cases are extremely rare [108-111]. In central Europe, bird-fancier's lung is the predominant clinical picture [106, 112-114].

\section{Allergic bronchopulmonary aspergillosis (ABPA)}

Allergic bronchopulmonary aspergillosis (ABPA) is a rare immunological lung disease involving sensitization (IgE and IgG antibodies) to Aspergillus antigens. It is caused by the inhalation of, and colonization by, Aspergillus spores that trigger an immune reaction. As part of this process, fungi may grow in the mucus-but not in tissue-and form hyphae. More rarely, allergic bronchopulmonary mycoses caused by Helminthosporium, Candida or other fungi may induce a similar picture. The clinical presentation of ABPA includes cough, worsening asthma, hemoptysis and tenacious mucus leading to mucus plugging. ABPA should be considered if more than 
two of the following criteria are met: cystic fibrosis; bronchial asthma; eosinophilia of unknown etiology; volatile antibiotic-resistant infiltrates; acquired central bronchiectasis; Aspergillus detection in sputum; expectoration of brownish mucus plugs; delayed cutaneous reaction to Aspergillus. The diagnosis of ABPA is based on the modified criteria originally proposed by Rosenberg et al. ([115]; Table 2). Recent investigations show that the combination of elevated total IgE (>1000 IU/l) and specific IgE against rAsp f 4 and rAsp f 6 permits the diagnosis of classic ABPA to be made with $100 \%$ specificity and $64 \%$ sensitivity. Treatment consists primarily of oral steroids; it is still not possible to generally recommend antifungal treatment. There are initial indications that treatment with omalizumab is able to reduce steroid requirements. Since ABPA can cause progressive fibrotic lung changes if left untreated, early diagnosis and treatment are important [116-120].

\section{Mycoses}

Infections caused by environmental fungi are referred to as exogenous mycoses. The diagnostic work-up and treatment of mycoses do not form part of the AWMF mould guideline; instead, only an assessment is made of the risk of infection upon exposure to indoor mould, since at-risk patients require individualized medical advice regarding consequences and preventive measures.

Fungal infections have increased in recent years [121, 122]. High incidence rates are seen above all in hemato-oncological patients with long phases of neutropenia, as well as in recipients of allogeneic stem cell transplantation. However, other forms of immunosuppression, such as prolonged corticosteroid use and interstitial lung disease (including residual cavitation, e.g. following tuberculosis [123, 124]), as well as a combination of these factors, especially in chronic obstructive pulmonary disease (COPD), have been linked to increased mould infection rates [125, 126]. Thanks to improved treatment options, hematological and oncological patients can now be treated for longer periods. However, this often leads to longer periods of increased infection risk, as well as recurrent neutropenia. Moreover, there is a trend toward relocating inpatient chemotherapy to the home environment [127]. This can result in increased exposure in the domestic setting during and/or directly after chemotherapy. Mould infections are among the most frequent causes of death due to infectious disease in hemato-oncological patients, and they are gaining in significance [121]. Mould-related mycoses in susceptible patients are usually acquired via the airways. Primary sites of infection are most commonly the lung and more rarely the paranasal sinuses, ear or injured skin. Originating in the respiratory tract, moulds can spread hematogenously or lymphogenically, thereby affecting other organs [23].
Although heat-tolerant Aspergillus species are only rarely found at high levels indoors (potentially in plant pots), they can be carried into indoor areas, e. g. due to close proximity to compost or waste treatment facilities, or as a result of anthropogenic effects (e.g. agricultural activities).

Individual cases of infection due to opportunistic moulds (mesophilic "environmental" species) have been described in the literature [128-133]. A recent analysis of altogether 53 aspergillosis outbreaks affecting 458 patients identified Aspergillus fumigatus and Aspergillus flavus as the most common species. Over $50 \%$ of affected patients came from hematology/ oncology departments.

In the hospital setting, (nosocomial) mould infections occur primarily as a result of Aspergillus and Mucor spore inhalation, contaminated materials, construction work or potted plants. Nosocomial infections are defined as the diagnosis of an infection $>48 \mathrm{~h}$ following inpatient admission. Immunosuppression generally occurs later, following chemotherapy lasting for several days. Spore inhalation, on the other hand, can occur earlier and also prior to inpatient admission. In this way, spores on the mucosa (e.g. the paranasal sinuses) may persist and only cause infection upon immunosuppression. This likely explains infections that occur even in maximum isolation and with high-efficiency particulate arrestance (HEPA) air filtration. As case studies demonstrate, mould infections can also occur outside the hospital setting [134-138]. The investigations conducted by Chen et al. [135] in Taiwan on pulmonary fungal infections revealed an increase in community acquired fungal infections. The link between building sites and demolition works and the resulting increase in fungal spore exposure in outdoor, as well as (secondarily) indoor, air is considered as established [139].

With regard to all reports on fungal infections, it must be borne in mind that it is not unequivocally clear whether these infections were acquired outside the hospital setting and/or outside of indoor spaces.

8.1 Invasive aspergillosis. Invasive Aspergillus infections are an important cause of morbidity and mortality in immunodeficient patients [140, 141]. Insufficient data is available on the incidence of aspergillosis in Germany; it is associated with high mortality rates (30-95\%) in the over 200,000 annual cases of lifethreatening Aspergillus infection worldwide [142].

The reader is referred to the joint guideline currently being drawn up by the German-speaking Mycological Society (Deutschsprachige Mykologische Gesellschaft, DMYKG) and the Paul Ehrlich Society (Paul-Ehrlich-Gesellschaft, PEG) for the diagnosis and management of (angio-)invasive bronchopulmonary aspergillosis, as well as to the "Invasive Fungal Infection" guideline according to the German Specialist society for the Diagnostics and Treatment of hematological and oncological Diseases. 
8.2 Aspergilloma. Aspergilloma (mycetoma or fungus ball) is a localized form of aspergillosis that generally develops in preformed cavities (paranasal sinus, lungs) due to a build-up of mould mycelia. Predisposing factors include, e. g. caverns secondary to tuberculosis, bronchiectasis and malignant disease [143, 144].

\section{Organic dust toxic syndrome (ODTS)}

Organic dust toxic syndrome is an acute, systemic flu-like disease caused by the inhalation of high concentrations of bioaerosols found almost exclusively in workplaces. It is significantly more common than HP (see Section “Toxicological diagnostics"), from which it is sometimes difficult to distinguish diagnostically [23, 102, 145]. Table 3 provides a decision-making aid for the differential diagnosis between HP versus ODTS. ODTS symptoms have been described in extremely high bioaerosol exposure. Exposure to high quantities of dust with an extreme bacterial load $\left(>10^{9}\right.$ spores/cubic meter, possibly less for Aspergillus fumigatus) [146] can cause asthma and pneumonitis [147], resembling HP symptoms. Granulomatous scarring and pulmonary fibrosis may be seen in the case of continued exposure [146, 148]. Details on the precise cause of the toxic irritant effect in ODTS are not known [4, 8].

\section{Pulmonary hemorrhage and acute idiopathic pulmonary hemosiderosis (AIPH)}

There is no rationale at present to assume a causal link between pulmonary hemorrhage and the presence of indoor mould [149, 150]. Nevertheless, a degree of association cannot be ruled out [151]. Medical history taking in children with AIPH should include questions about dampness/mould [152].

\section{Susceptibility to infection}

There is evidence of a consistent association between water damage or indoor mould exposure and the development of medically diagnosed respiratory tract diseases (common cold, bronchitis, infections) [21].

Fisk et al. [41] estimate that $8-20 \%$ of respiratory tract infections in the US are associated with mould or indoor dampness. The link continues to exist even after controlling for independent variables. Penicillium

Table 3 Differential diagnosis between hypersensitivity pneumonitis $(H P)$ and organic dust toxic syndrome (ODTS) [8]

\begin{tabular}{|l|l|l|}
\hline $\begin{array}{l}\text { Characteristic } \\
\text { Exposure }\end{array}$ & Various allergens & $\begin{array}{l}\text { ODTS } \\
\text { Endotoxins, high expo- } \\
\text { sure }\end{array}$ \\
\hline Incidence & $2-30 / 10,000$ & $10-100 / 10,000$ \\
\hline Latency & $4-8 \mathrm{~h}$ & $4-12 \mathrm{~h}$ \\
\hline Auscultation & $\begin{array}{l}\text { Bilateral basal end-expiratory } \\
\text { crackles }\end{array}$ & $\begin{array}{l}\text { Normal, crackles possi- } \\
\text { ble }\end{array}$ \\
\hline $\begin{array}{l}\text { Pulmonary } \\
\text { function }\end{array}$ & $\begin{array}{l}\text { Restricted (infrequently ob- } \\
\left.\text { structed, low } D_{\mathrm{LCO}}\right)\end{array}$ & $\begin{array}{l}\text { Normal (possibly re- } \\
\text { stricted) }\end{array}$ \\
\hline Precipitins & Often specific lgG & Usually negative \\
\hline
\end{tabular}

sp., Cladosporium sp., zygomycetes and Alternaria sp. proved to be most closely linked to the development of these diseases.

The mechanism of this association appears to be non-allergic in nature [153].

\section{Irritant effects-mucous membrane irritation (MMI) and chronic bronchitis}

Besides a variety of environmental factors, dampness [154] and moulds [155] are associated with mucosal irritation, referred to as mucous membrane irritation $(\mathrm{MMI})^{1}$, and chronic bronchitis [156]. Although the pathophysiological links between exposure to these environmental factors and MMI or chronic bronchitis have not been elucidated as yet, the mucosal epithelium and local neurons have been attributed with a key role in MMI [157]. According to a Danish study, long-term exposure to damp indoor spaces causes mucosal hyperreactivity in nasal histamine provocation that persists even after remediation [158].

The prevalence of mucosal irritation among individuals occupationally or environmentally exposed to bioaerosols is put at approximately 20-30\% [159-161]. There are no reliable data as yet-in general or specifically for indoor mould exposure-on the prevalence of these non-allergic, irritant, inflammatory effects.

Possible irritant symptoms in MMI include nonspecific irritation of the mucous membrane of the eye (e. g. burning, watering, itching), the nose (e.g. sneezing, secretion and obstruction of the nasal cavity) and the throat (e.g. feeling of dryness, clearing of the throat). In addition, irritant inflammatory processes in the deeper airways (e.g. cough) may manifest as chronic bronchitis [156]. Symptoms seen during exposure, such as coughing, burning, itching of the eyes and nose and skin irritation, resolve rapidly once exposure ceases. From a differential diagnostic perspective, it is important to distinguish allergic symptoms that, unlike irritant reactions, generally increase upon repeated and long-term exposure due to sensitization [162]. The irritant toxic effects of moulds can possibly be attributed to metabolites or cell wall components (glucans), as well as to a reaction to the release of interleukins or other inflammatory mediators [39]. As part of this, synergistic effects of various mycotoxins and/or mycotoxins with other microbiological agents (e. g. glucans, endotoxins from bacteria) may be responsible for this effect [32, 34, 163-165].

\section{Sarcoidosis and moulds}

In sum, there is only unreliable evidence that different forms of microbial inhalation exposure, including water damage, can increase the risk of developing sarcoidosis; no causal link between mould exposure and sarcoidosis has been established as yet [166, 167].

\footnotetext{
1 Sometimes also referred to as mucous membrane irritation syndrome (MMIS).
} 
Thus, in future studies on the etiology of sarcoidosis, it would make sense to pose questions regarding inhalant-including infectiological-factors and water damage in patients' domestic and occupational environments during medical history taking [168-173]. However, there is currently insufficient data to assume a causal link between the development or exacerbation of sarcoidosis and water damage or mould exposure.

No specific mould-related diagnostic work-up is indicated in sarcoidosis above and beyond the usual procedure.

\section{Rheumatic disorders}

Infections (bacterial, viral) have long been discussed as triggering factors in numerous inflammatory rheumatic diseases. A working group has produced evidence of a link between moisture damage and rheumatic disorders [174-177]. The occurrence of a cluster in one building was attributed to the presence of moisture damage and "abnormal" microbial exposure [175].

However, until studies from other centres (and countries) are available, one cannot assume that the current evidence is sufficiently robust. Given that the epidemiological evidence is insufficient, it is not possible to make any statements on incidence or any possible links between mould exposure and/or moisture and rheumatic disease.

No specific mould-related diagnostic work-up is indicated in rheumatic disorders (interdisciplinary guideline, management of early rheumatoid arthritis) above and beyond the usual procedure.

\section{Mycotoxicosis}

Systemic effects (poisoning) caused due to the mycotoxins produced by moulds are referred to as mycotoxicosis and are known to occur upon oral ingestion of contaminated foods [105].

There is no reliable knowledge to date of indoor airborne mycotoxin poisoning. It also remains to be established whether mycotoxin levels in indoor air are relevant in terms of a systemic toxicological risk. According to the findings available to date, this does not appear to be the case.

\section{Odour effects}

Mould metabolites can cause relevant odours to be perceived [178]. This should prompt a structural investigation into the cause of indoor moisture/mould damage.

The term microbial volatile organic compounds (MVOC) refers to volatile organic compounds produced by moulds and bacteria [178-180]. It is important to bear in mind that there are also other sources of MVOC besides microbial sources (tobacco smoke, cooking, baking, roasting, pot plant soil, compost bin etc.) [181]. It has not yet been elucidated whether biological signalling effects come from MVOC at the low $\mu \mathrm{g} / \mathrm{m}^{3}$-range levels found indoors [182]. Olfactory-psychological coupling reactions with nonspecific symptoms are possible in the case of cacosmiarelated abnormalities; toxic reactions, on the other hand, are unlikely [183, 184].

Environmental odours can affect health and wellbeing in various ways. A distinction needs to be made between: direct physiological effects; odour perception; odour pollution as an effect of the odour on an emotional level; and indirect physiological effects due to odour pollution and the resulting chronic stress. In the reality of environmental health analysis, it is not always possible to distinguish between the health effects caused by odours via the above-mentioned mechanisms.

The characteristic effect of unpleasant odours is that they pose a nuisance. Although mood disorders as a health effect are possible, these are not mediated via toxicological mechanisms, but rather via conditioning, attribution (of links), or stress. Mood disorders can be understood as precursors to somatic dysfunction. Typical symptoms due to highly unpleasant odour pollution can include fatigue, lack of concentration, nausea, headache and insomnia [185].

The perception and cognitive appraisal of - and thus also sensitivity to-odours are subject to considerable inter-individual variability. Genetic and hormonal factors, as well as character, context and adaptation effects, play a role here [186].

\section{Mood disorders and nonspecific symptoms}

Mood disorders are defined as "a deterioration in psychological, physical, and social well-being and feeling of subjective performance capacity. As an emotional experience, they need to be distinguished from stress responses, which include a cognitive evaluation of specific environmental stimuli" [187, 188]. Mood disorders play a crucial role in environmental health disorders in general, as well as in health disorders related to indoor environments in particular [189]. Three models are used to explain the mode of action of these types of environment-related mood disorders: the noxious agent model, the attribution model and the stress model $[187,188]$. It is possible in principle that environment-related mood disorders could be triggered by moulds, e.g. as a result of odours [189].

\section{Neuropsychological and neurotoxic effects}

The specialist literature does not point to a consistent causal relationship between indoor toxin levels and neurotoxic effects [43, 190-193]. Evidence of a link is insufficient [194].

\section{Gastrointestinal effects, renal effects, teratogenicity and cancer}

To date, there have been no systematic investigations or case descriptions that provide evidence of, or suggest an association between, indoor moisture damage or mould and gastrointestinal or renal disease, repro- 
Table 4 Risk groups among immunosuppressed individuals according to the Commission for Hospital Hygiene and Infection Prevention (Kommission für Krankenhaushygiene und Infektionsprävention, KRINKO) at the Robert Koch-Institute [11]

Risk group 1 (moderate immunosuppression/-deficiency)

- Granulocytopenia $<0.5 \times 10^{9} / /\left(<500 / \mu\right.$ l) for up to 10 days (similarly, leukopenia $<1 \times 10^{9} /$; $<1000 /$ ul)

- Deficiency of CD4-positive T-helper cells $<250 / \mu l$ (note: age-appropriate normal values in children); autologous stem cell transplantation up to 3 months following intensive treatment phase

Patients exhibiting more than one feature of immunosuppression/-deficiency listed in risk group 1 come under risk group 2

Risk group 2 (severe immunosuppression/-deficiency)

- Granulocytopenia $<0.5 \times 10^{9} / \mathrm{l}\left(<500 /\right.$ ul) for more than 10 days (similarly, leukopenia $<1 \times 10^{9} / \mathrm{l} ;<1000 /$ ul)

- Severe aplastic anaemia or macrophage activation syndrome under intensive immunosuppressive treatment

- Allogeneic bone marrow or stem cell transplantation up to 6 months following completion of intensive treatment (important: degree of the graft-versus-host disease (GVHD) and continued iatrogenic immunosuppression)

- Acute inpatient treatment phase in autologous stem cell transplantation or following solid organ transplantation (up to hospital discharge)

Risk group 3 (very severe immunosuppression/-deficiency)

- Allogeneic bone marrow transplantation/allogeneic blood stem cell transplantation (PBSCT) in the intensive treatment phase (until engraftment $=$ regeneration of granulopoiesis)

- Severe grade III or IV GVHD under intensive immunosuppression

The decision on whether to assign allogeneic stem cell transplantation patients to group 3 is ultimately taken by considering an overview of all findings from the treating oncologists

ductive disorders, teratogenicity or cancer (see $[20$, 150]).

It is the physician's duty to investigate a possible causal link in such cases.

\section{Risk analysis and assessment}

\section{Risk of infection}

The risk of infection from common indoor mould species is low in healthy individuals; most species are classified in risk group 1 and only a handful in risk group 2 (Aspergillus fumigatus, A. flavus) of the German Biological Agents Act [195].

The current German Biological Agents Act, which regulates occupational tasks involving (the handling of) moulds, classifies the risk of infection from biological agents at the workplace into four risk groups [196], whereby moulds fall into risk groups 1 and 2:

- Risk group 1: Biological agents that are unlikely to cause human disease.

- Risk group 2: Biological agents that can cause human disease and might pose a hazard to workers; it is unlikely to spread to the community; effective prophylaxis or treatment is usually available.

- Risk group 3: Biological agents that can cause severe human disease and pose a serious hazard to workers; there may be a risk of spreading to the community, but effective prophylaxis or treatment is usually available.

- Risk group 4: Biological agents that can cause severe human disease and pose a serious hazard to workers; there may be a high risk of spreading to the community; effective prophylaxis or treatment are usually not available (risk group 4 does not include any fungi).

Mould mycoses are opportunistic infections. They require exposed individuals to have reduced immune status. Heat-tolerant mould species in risk group 2 (e. g. A. fumigatus, A. terreus, A. niger, A. flavus, Emeri- cella nidulans and mesophilic Fusarium sp.) of the classification of moulds into risk groups according to the Technical Rules on Biological Agents (TRBA 460) [195] in the German Biological Agents Act [196] only rarely cause infections in healthy, immunocompetent individuals; however, they can trigger mycosis in individuals whose immune system is incompetent due to disease or other factors [197, 198].

According to KRINKO at the Robert Koch-Institute [11], immunosuppressed individuals can be classified into three risk groups (Table 4). Patients at particular risk include (in descending order of risk): cancer patients, in particular those with underlying hemato-oncological disorders (e.g. leukaemia, lymphoma), acute myeloid leukaemia (AML), acute lymphatic laeukemia (ALL), allogeneic stem cell transplantation, autologous stem cell transplantation, solid organ transplantation, HIV infection, other forms of immunosuppression (e.g. a long-term high-dose treatment with glucocorticoids), aplastic anaemia and cystic fibrosis, among many others [121, 199]. AML is associated with the highest incidence of invasive mould infections (around 12\%) and the most mould infections (around 8\%). This is followed by ALL at around $4 \%$. Among the procedures, allogeneic hematopoietic stem cell transplantation (allo-HSCT) is associated with an extremely high incidence of mould infections [121].

Due to the continuously rising proportion of immunosuppressed patients in the population and the ever longer survival rates among this patient group, it is not possible at present to exclude the possibility that mould infections may become a growing health risk factor in this population group [8].

It is not possible to calculate a numerical risk on the basis of current knowledge. Risk matrix 1 (Fig. 1) shows a semiquantitative risk assessment of the risk of infection due to indoor moulds. 
Fig. 1 Riskmatrix 1: Risk of mould-related infection (the darker the box, the greater the possible health risk)

\begin{tabular}{|l|l|l|l|l|}
\hline Moulds & $\begin{array}{c}\text { Predisposition } \\
\text { No immune- } \\
\text { suppression }\end{array}$ & $\begin{array}{c}\text { Moderate } \\
\text { immune- } \\
\text { suppression }\end{array}$ & $\begin{array}{c}\text { Severe } \\
\text { immune- } \\
\text { suppression }\end{array}$ & $\begin{array}{c}\text { Very severe } \\
\text { immune- } \\
\text { suppression }\end{array}$ \\
\hline $\begin{array}{l}\text { Generally non-infectious } \\
\text { moulds, e.g. } \text { C. } \\
\text { herbarum, } \\
\text { C. cladosporioides }\end{array}$ & & & \\
\hline $\begin{array}{l}\text { Rare opportunistic } \\
\text { infectious moulds (risk } \\
\text { group 1 according to the } \\
\text { German Biological } \\
\text { Agents Act [195]), } \\
\text { e.g.: } \text { A. niger, } \text { A. clavatus, } \\
\text { Alternaria alternata }\end{array}$ & & & & \\
\hline $\begin{array}{l}\text { Opportunistic infectious } \\
\text { moulds (risk group 2 } \\
\text { according to the German } \\
\text { Biological Agents Act } \\
\text { [195]), } \\
\text { e.g.: A. fumigatus, } \\
\text { A. flavus }\end{array}$ & & & & \\
\hline
\end{tabular}

Fig. 2 Riskmatrix 2: Risk of mould-related sensitization/ allergization (the darker the box, the greater the health risk). ${ }^{*}$ Evidence is required of the clinical relevance of sensitization as detected by allergy testing!

\begin{tabular}{|c|c|c|c|c|c|}
\hline Predisposition & & ergy & Allergy* & & \\
\hline 4 & $\begin{array}{c}\text { without } \\
\text { family } \\
\text { disposition }\end{array}$ & $\begin{array}{l}\text { with family } \\
\text { disposition }\end{array}$ & $\begin{array}{l}\text { without } \\
\text { mould } \\
\text { allergy }\end{array}$ & $\begin{array}{l}\text { Allergy* to } \\
\text { moulds }\end{array}$ & $\begin{array}{c}\text { Allergy }{ }^{*} \text { to } \\
\text { specific moulds }\end{array}$ \\
\hline Moulds with & & & & & \\
\hline $\begin{array}{l}\text { sensitizing/allergizing } \\
\text { effects, e.g.: Alternaria }\end{array}$ & & & & & \\
\hline alternata, & & & & & \\
\hline $\begin{array}{l}\text { A. fumigatus, } \\
\text { P. chrysogenum, }\end{array}$ & & & & & \\
\hline Cladosporium sp. & & & & & \\
\hline
\end{tabular}

\section{Risk of sensitization/allergy}

In principle, there is a possibility of sensitization and the triggering of a clinically symptomatic allergy also among healthy individuals following inhalation of spores and other mould components (e.g. mycelium). The sensitizing potential of moulds is considered significantly lower $[177,202-204]$ compared with allergens from, e. g. fur-bearing pets, grass and tree pollen or house dust mites [200, 201]. Recent populationand patient-based [13] studies reveal a comparatively low prevalence of sensitization across Europe of $3-10 \%$ measured relative to the total population [12]. It can be said as a general rule that sensitization-also to moulds-is not equivalent to a clinically relevant allergy. It is generally assumed that there are over one million mould species. Around 350 mould species have been listed on www.allergome.org as potentially sensitizing. However, it is not possible to infer how high the total percentage of sensitizing moulds is on the basis of this information. At present, 107 mould proteins from 43 mould species fulfil the WHO/IUIS criteria for classification as an allergen (www.allergen. org). Only a handful of moulds are available as test allergen solutions and typical indoor fungal allergen extracts are largely lacking $[38,205]$.

From an allergological perspective, an exposure dose-dependence (measured as colony forming units, $\mathrm{CFU}$ ) does not alone determine the clinical reaction in mould-sensitized patients. Sensitization with the formation of specific IgE antibodies and the triggering of allergic reactions takes place on the protein or peptide-component level. Thus, it is not necessary for whole spores or intact mould mycelium to be present. Allergenicity depends far more on the 
proteins or peptides which, due to their properties, are allergy-triggering. ${ }^{2}$

Exposure to damp indoor spaces represents a risk factor for developing bronchial asthma in individuals with atopy, rhinoconjunctivitis and rhinosinusitis. In the case of rhinosinusitis associated with mould exposure, the risk for developing bronchial asthma doubles (Odds ratio [OR]: 2.2; confidence interval [CI]: 1.3-3.6) [206]. Young atopic children appear to be at higher risk for developing bronchial asthma in the case of moisture damage or mould exposure in the bedroom or living room [207].

It is not possible to calculate a numerical risk value on the basis of current knowledge. Risk matrix 2 (Fig. 2) shows a semiquantitative risk assessment of the risk of sensitization/allergy due to indoor moulds.

\section{Risk of toxic/irritative effects}

Only those moulds that are potentially able to form toxins come into consideration as triggers of intoxication. Whether indoor toxin formation takes place in individual cases depends on environmental and growth conditions and, in this regard, most notably on the substrate $[150,208]$.

No predisposing factors for mycotoxin intoxication in humans are known. However, predisposition on a target-organ level is conceivable. For example, it is imaginable that pre-existing liver disease (e. g. chronic hepatitis, liver cirrhosis) could represent a predisposition for the hepatotoxic effects of aflatoxin following oral ingestion of this toxin. Whether this also applies to airborne toxin intake remains hitherto unclear [8].

It is not possible to calculate a numerical risk on the basis of current knowledge [43].

It is unclear to date whether persons affected by MMI or chronic bronchitis are particularly sensitive individuals and react even to small doses, or whether sensitized individuals react differently, independent of dose, compared with non-sensitized individuals [157]. Other inflammatory processes in the area of the mucosa of the eyes and respiratory tract, such as infections, atopic mucosal disorders, keratoconjunctivitis sicca and dry nasal mucosa, can be possible predisposing factors for MMI and chronic bronchitis [8].

\section{Risk of odour effects and mood disorders}

In principle, odour effects and/or mood disorders as a result of indoor moisture/mould damage can

\footnotetext{
${ }^{2}$ Definition of the term "allergen": Allergens are antigens which cause allergy. Most allergens reacting with IgE and IgG antibody are proteins, often with carbohydrate side chains, but in certain circumstances pure carbohydrates have been postulated to be allergens. In rare instances, low molecular weight chemicals, e.g. isocyanates and anhydrides acting as haptens, are still referred to as allergens for IgE antibodies (WAO/EAACI Allergy Definitions, http://www.worldallergy.org/professional/allergic diseases_center/nomenclature/english.php).
}

affect anyone. This does not represent a health risk. Predisposing factors for odour effects may include genetic and hormonal influences, character, context, and adaptation effects [186].

Predisposing factors for mood disorders may be environmental concerns, fears, conditioning, and attributions, as well as numerous diseases [209].

\section{Diagnostic work-up}

\section{Reason for seeking medical advice}

Patients generally seek medical advice in conjunction with mould exposure for the following reasons [105, 162]:

1. Patients experience health problems, the circumstances of which suggest an environment-related link to moisture damage and/or mould exposure.

2. Patients have mood disorders and nonspecific symptoms that are in clear temporal relationship to certain environmental/ambient conditions or activities.

3. Patients are concerned about possible mould exposure.

4. Measurements are already available.

5. Medical support is sought in rental and construction disputes.

\section{Diagnostic work-up: general procedure, medical history, physical examination and clinical chemical and instrument-based tests}

Medical history [210] and physical examination are the basic elements of any medical diagnostic workup. On the basis of these, further special investigations are performed within the relevant medical specialty depending on the diagnostic question and differential diagnostics. In addition, in environmental and occupational medicine, investigations to internal exposure (human biomonitoring in the form of exposure and/or effect monitoring) and/or external exposure (home/site visit, environmental monitoring) are always performed if possible and where indicated.

\section{Medical history}

Medical history taking should involve a holistic approach that is not confined to environmental exposure and aspects of physical disease alone, but one that also takes the psychosocial dimension equally into account. This approach, which is particularly necessary in view of the patient's high expectations of the physician, should be explained to the patient. Giving equal priority to psychological and social aspects rarely produces difficulties in the consultation setting once the approach has been explained to the patient.

In addition to the general and differential diagnostic history, the following elements should be consid- 
ered during medical history taking in the case of suspected health disorders due to mould:

- history of exposure in the home,

- history of exposure in the workplace,

- history of exposure during leisure time,

- history of infections, including predisposing factors,

- history of allergies, including predisposing factors,

- history regarding irritant toxic effects,

- history regarding odour effects,

- history regarding mood disorders.

Physical examination

A complete, or at least symptom-oriented, physical examination always forms an integral part of medical history taking. The method of physical examination is based on inspection, palpation, percussion, auscultation and functional testing.

The target organs noted in the medical history should take priority in the examination. Particular attention should be paid to the mucosa of the eyes and, as far as possible, upper airways, as well as to the skin, since the nonspecific symptoms that patients often complain of relate to these organs in particular [22, 211]. As a basic rule, the physical examination should be performed in a structured and standardized manner and should be adequately documented. A variety of clinical finding forms are available to this end.

\section{Markers of mould exposure}

\section{Environmental monitoring}

As a rule, there is no medical indication to determine mould indoors, in building materials or on fixtures.

From a medical perspective, a visual inspection of mould infestation is sufficient to initiate medically justified measures. The greatest relevance is attributed to site visits, which are ideally performed by a physician and experts with structural expertise.

In the case of visible mould infestation, increased moisture levels in materials or structural abnormalities (moisture or water damage), the identification and quantification of indoor mould is not indicated from a diagnostic and therapeutic perspective [212].

The differential diagnosis always takes priority when assessing the health effects of mould exposure. Since the effect of mould depends primarily on the disposition of the affected individual, any delay caused through mould determination in taking steps may put persons requiring particular protection from mould at increased risk. Risk groups warranting particular protection include:

- immunosuppressed individuals according to the three risk groups defined by the KRINKO at the Robert Koch-Institute [11],

- individuals with cystic fibrosis (mucoviscidosis),

- individuals with bronchial asthma.
In the above-mentioned patient groups, tests on the basis of relevant suspicion are seldom medically indicated to assess risk purely for preventive purposes.

Gabrio et al. (2015) recently presented a summary of test methods available to ascertain mould exposure in indoor mould infestation, e. g. due to moisture damage [213]. Their summary is designed to provide not only treating physicians, but also environmental mycologists, indoor diagnosticians, craftsmen, architects and building experts responsible for ordering or evaluating measurements, with sound knowledge about useful (or redundant) applications and the reliability of the various measuring and test methods, thereby making a solid basis available for the commissioning or assessment of relevant tests. The reader is referred to the pertinent literature for a more in-depth discussion of this topic [2, 4, 214, 215].

\section{Clinical diagnostics}

\section{Allergy diagnostic work-up}

The diagnostic work-up here does not differ from that in other allergic diseases. A stepwise approach is taken that considers individual factors according to the classic step-by-step model: medical history/physical findings/clinical investigation-skin tests-serum analysis or complementary in vitro methods-provocation $[89,216]$.

Allergic disorders due to mould allergens can essentially manifest as conjunctivitis, rhinitis, rhinosinusitis, allergic bronchial asthma, urticaria, HP and ABPA. As a result, the differential diagnosis based on medical history and clinical laboratory in vitro/ in vivo testing is of central importance. In individual cases, the allergic reaction needs to be confirmed and the allergy trigger identified. There is a wide variety of in vitro tests to measure parameters of the cellular and humoral allergic reaction on different levels. However, the repertoire of commercially available mould allergen extracts is limited and primarily covers typical species found in outdoor air.

Particularly in in vitro testing, it is important to bear in mind that increased mould-specific IgE levels, for instance, can indicate sensitization to mould allergens, but do not equate to allergic disease. A correct interpretation of results is only ever possible in conjunction with the medical history, clinical picture and/or the results of organ-specific provocation tests. Given the possibilities for exposure (ubiquitous outdoor exposure, indoor exposure and occupational exposure), evidence of positive sensitization to mould needs to be regarded critically in the assessment of causality. It is extremely rare in routine allergology/ environmental medicine for a causal link to be reliably confirmed between indoor mould exposure and an associated specific sensitization and disease (rhinitis, conjunctivitis, asthma) [8].

The following conditions need to be met in order for a mould allergy to be diagnosed [217]: 
- A pathogenic mould antigen is present in the environment.

- There is an unequivocal temporal relationship between allergic symptoms and exposure to the mould allergen.

- Atopic predisposition is present.

- There is evidence of specific IgE formation to mould antigens.

- Measures to avoid mould allergens exhibit clear clinical effects.

In principle, the same recommendations and guidelines apply to the diagnostics of mould allergy as to other allergen sources that cause immediate-type allergies [218].

1.1 Serological investigations. Serological in vitro tests include specific IgE antibody determination in the case of IgE-mediated disease, or specific IgG antibody determination in the case of HP. Although the identification of elevated specific antibodies is a clear indication of sensitization, this does not equate to clinical relevance; having said that, the predictive value for clinical relevance increases according the degree of sensitization [219].

1.2 Identification of mould-specific IgE antibodies. The identification of allergen-specific IgE indicates specific sensitization, but not necessarily disease; results can only be correctly interpreted in conjunction with medical history, clinic picture and the results of organ-specific provocation tests. Positive reactions caused by cross-sensitivity are of only partial clinical relevance.

A quantitative comparison of results from different test systems is challenging (call for international standards).

A call needs to be made for the improvement of reagent quality by standardizing the allergens and defining minimum requirements for the allergencarrier material (determining diagnostic efficacy).

Extracts of indoor-relevant moulds should also be commercially available in adequate quality.

The spectrum of available single allergens from the relevant moulds needs to be expanded.

1.3 Mould-specific IgG determination. Only in the case of suspected ABPA (type I and III allergy) or HP (type III and IV allergy) can mould-specific IgG antibody determination make a helpful contribution to diagnosis and, as such, be recommended [101, 107].

In ABPA, a significant increase is seen not only in total IgE and specific IgE against A. fumigatus (see above), but also in specific IgG against A. fumigatus. The latter is markedly elevated compared with patients allergically sensitized to A. fumigatus and is therefore recommended in the differential diagnosis of ABPA.
1.4 Cytokines and eosinophil cationic protein (ECP). There is no special indication for these nonspecific markers of eosinophil activation and recruitment in the identification of mould allergy.

1.5 Immune complex analysis. The analysis of immune complexes is confined to particular disorders in the realm of type III allergic reactions, such as HP, and has no place in the diagnostics of mould exposure beyond this (see mould-specific IgG determination above).

1.6 Galactomannan in serum. The detection of serum galactomannan for diagnostic purposes is only indicated in invasive aspergillosis [220].

$1.7 \beta-1,3-D-g l u c a n$ in serum. The detection of $(1 \rightarrow 3)-\beta$-D-glucan in serum is technically challenging and could be helpful in the diagnostic work-up of invasive mycosis. Its application is not indicated in conjunction with indoor mould [221].

1.8. Mycotoxins in serum. Current analytical possibilities do not permit the reliable determination or evaluation of indoor mycotoxin exposure. The determination of mycotoxins in blood, serum or urine is of no relevance in practical medicine and must remain confined to scientific investigations for the time being.

\section{Cellular assays}

Rare indications for tests with the "basophil granulocyte" target cell include samples with extremely low total IgE and failed specific serological IgE detection in the case of suspected sensitization or exotic allergens.

2.1 The basophil degranulation test and histamine release. The histamine release test (HRT) is not helpful in the diagnostics of mould allergy.

2.2 The basophil activation test by flow cytometry (Flow CAST). This test is beneficial in the case of inhalant allergens, particularly when skin testing and specific IgE measurements are not possible. Rare indications include samples with low total IgE, failed serological specific IgE detection and possibly negative skin tests in suspected sensitization or exotic allergens.

\subsection{Determination of other effector-cell mediators} (leukotriene release test, cellular antigen stimulation test [CAST]). Testing positive to an allergen, which represents an indirect identification of sensitization, is only indicative of a clinically relevant allergy in conjunction with a positive medical history and/or positive provocation tests. This test is also complex to perform and not suited to routine diagnostics. 
2.4 Lymphocyte transformation test. Since mould allergens do not cause type IV sensitization, lymphocyte transformation testing for mould is not indicated as a diagnostic method [14].

\section{Provocation tests}

In cases where medical history, physical examination and serology fail to unequivocally establish the diagnosis of a mould allergy, provocation testing may be indicated if this will significantly impact treatment, prevention and/or compensation [222]. Organ-specific provocation testing is aimed at confirming the clinical relevance of existing sensitizations or supposedly observed symptoms.

At present, only a few commercial mould allergen test extracts are available from a handful of manufacturers. As shown in investigations published by Kespohl et al. [223] in 2013 using detailed biochemical and immunological analysis, mould allergen extracts exhibit high variability in terms of allergen composition, and preparations of a fungal species are not comparable between different manufacturers. Skin test extracts of the outdoor mould Alternaria are an exception here.

3.1 Skin testing. After medical history, skin tests (ST) form the basis of the allergy diagnostic work-up and are fast and relatively cost-effective to perform. As a general rule, they are sufficiently meaningful and are associated with a low complication rate. ST should be performed according to the relevant German or European position papers [224].

A distinction is made in skin testing between epicutaneous (patch, friction) and cutaneous (scratch, skin prick and intracutaneous) tests. The allergen concentration in solutions used for intracutaneous testing is usually 100 - to 1000 -fold lower compared with skin prick test solutions. However, since intracutaneous test solutions have not been commercially available since June 2015, this diagnostic method to detect mould sensitization no longer applies.

3.2 Nasal provocation testing. The nasal provocation test (NPT) makes it possible to reproduce an allergic reaction at the manifesting organ under standardized conditions and is considered a simple and safe method with high specificity and sensitivity [224-227]. It is recommended that tests be performed and evaluated according to standards set out in the German Society for Allergology and Clinical Immunology (Deutsche Gesellschaft für Allergologie und klinische Immunologie, DGAKI) guideline [228].

Inhalation allergies to mould spores generally cause persistent respiratory tract symptoms; this can make it challenging to establish an unequivocal relationship to the medical history. In this context, NPT is able to confirm or exclude a suspected diagnosis of an allergic reaction of the respiratory tract. NPT is also indicated in cases where skin testing is contraindicated or local allergic rhinitis is suspected, and to monitor the course of treatments such as allergen specific immunotherapy (SIT).

3.3 Conjunctival provocation testing. The conjunctival provocation test (CPT) should only be performed when the patient is free of symptoms; standardized skin prick test solutions (1:10 dilution, possibly higher) are generally used [229].

A CPT may be indicated if

- symptoms are predominantly conjunctival,

- an NPT for nasal symptoms is not possible due to contraindications or recent endonasal surgery.

3.4 Bronchial provocation testing. A bronchial provocation test (BPT) may be indicated if it is not possible to establish the diagnosis on the basis of a combination of exposure tests and less invasive diagnostic tools, such as medical history and skin testing. Medical history is generally not helpful, particularly in perennially occurring indoor moulds. Optionally, there is an indication to confirm diagnosis prior to hyposensitization, as well as in cases where a courtadmissible expert opinion on a link to a particular instance of exposure is required [222]. As with other inhalant allergens, the degree of sensitization can be taken into account as a guide. As such, the BPT plays an important role in suspected allergic perennial asthma due to indoor moulds. Allergen selection should be guided by the spectrum of sensitization. The evidence for provocation testing in the event of failure to detect sensitization is insufficient, meaning that no recommendation can be made in this regard. The spectrum of commercial extracts available for provocation testing is progressively narrowing. The test must be performed according to the relevant guidelines. When assessing allergen provocation tests, one should expect false-positive as well as false-negative reactions. It is generally problematic to make any statements on sensitivity and specificity in the absence of a clinically relevant gold standard, a situation made more challenging in the case of moulds due largely to the lack of investigations on the quality of test extracts. Recent Finnish studies on occupational mould exposure show that provocation testing with commercial mould extracts may be significantly more sensitive compared with the detection of sensitization [230]. These data require validation. It is therefore challenging to assess provocation reactions in mould provocation tests, partly since often isolated delayed reactions are described [230].

\section{Diagnostic work-up for infections}

The reader is referred to the relevant guideline for details on the procedure in mould infections (systemic mycoses). 


\section{Toxicological diagnostics}

There are currently no practicable and validated test methods that could be applied in clinical diagnostic practice.

\section{Unconventional diagnostic methods}

Due to a lack of evidence, unconventional (or unconventionally used) diagnostic methods [231-233] are not advised.

\section{Treatment}

Even if no causal link can be established between symptoms/findings/disorders and the occurrence of indoor mould/dampness, the first "therapeutic" measure to be undertaken from a preventive and hygienic perspective in the case of dampness/mould damage is prompt appropriate and professional remediation; moreover, in the case of severe clinical pictures associated with high risk (immune suppression according to KRINKO criteria [11], cystic fibrosis [mucoviscidosis], asthma), immediate minimization of exposure needs to be achieved.

\section{General drug treatment}

In principle, topical and/or systemic treatment is indicated in mould allergy depending on the organ-specific manifestation of the allergic disorder.

The reader is referred to the relevant guidelines for more details on (organ-specific) drug treatment of allergies.

\section{Specific immunotherapy (hyposensitization)}

Specific immunotherapy (SIT) using mould extracts should be applied as early in the disease course as possible, particularly if drug treatment and avoidance have previously failed to stabilize symptoms [234]. The relevant mould allergens need to be unequivocally confirmed at diagnosis as the trigger of allergic symptoms. The prerequisite for SIT is evidence of clinically relevant allergen-specific IgE sensitization. The combination of different test methods, together with medical history, provides an adequate basis for SIT. Hyposensitization presupposes a confirmed diagnosis. In this regard, the reader is referred to the current guideline [235].

According to current data, only a handful of studies support the efficacy of SCIT in the outdoor-relevant moulds Alternaria alternata and Cladosporium herbarum [236, 237].

There is insufficient scientific evidence to date to support the efficacy of sublingual immunotherapy (SLIT) in terms of hyposensitization to indoorrelevant moulds.

\section{Exposure avoidance}

As with all allergic diseases, exposure avoidance (allergen avoidance) takes priority. Nevertheless, prompt medication is required in order that a symptom-free period is not followed by full-blown allergic disease. It is of paramount importance to eliminate the causes of the dampness creating a basis for indoor mould growth. The AWMF mould guideline [1] provides recommendations for indoors, outdoor air and foods (recommendations without evidence).

\section{Unconventional treatment methods}

As with all medical procedures, unconventional treatment procedures [231-233] need to be tested and evaluated according to current scientific knowledge and will only be reimbursed by health insurers if the therapeutic benefit is proven.

\section{Remediation of living areas (buildings) affected by dampness and mould growth}

Proper remediation of dampness/mould damage includes the elimination of structural cause(s), the drying out and removal of all mould-infested materials as well as subsequent fine cleaning. Details of these procedures do not form part of this guideline. More detailed information can be found in the relevant mould guidelines $[2,3,5]$, as well as the revised version of the UBA guideline (due to be published 2017).

\section{Social status and dampness/mould infestation}

Statistical surveys show that dampness/mould damage is more frequently reported in homes of individuals with low social status compared with the general population (e.g. German Federal Statistical Office, 2006). This gives rise to particular problems for low-social-status individuals in terms of the likelihood of dampness/mould damage and its remediation [1].

\section{Prevention}

It is important, as a first step, to provide susceptible and immunosuppressed patients with information on the risks associated with indoor mould exposure and preventive measures [238, 239], possibly supplemented by home visits to inspect for Aspergillus fumigatus and Aspergillus flavus (only rarely found indoors) [240].

Prevention and exposure avoidance are paramount in all cases of health-related disorders associated with exposure to environmental factors. This applies in particular to moulds. To ensure allergy prevention, it is essential to avoid an indoor climate that promotes mould growth (high air humidity, lack of ventilation) [241]. 
Further information can be found in the UBA guideline on mould [2], as well as the revised version of the UBA guideline (due to be published 2017).

Consensus procedure. Guideline Commission, the German Society of Hygiene, Environmental Medicine and Preventive Medicine (GHUP) (Gesellschaft für Hygiene, Umweltmedizin und Präventivmedizin, GHUP)

\section{Facilitator. Prof. Dr. Gerhard A. Wiesmüller, Cologne,} Germany

Conflict of interest Information relating to potential conflicts of interest was evaluated by the steering committee; no conflicts of interest that might compromise authors' professional independence in the drawing-up of this guideline were identified. Conflict of interest statements can be found and called-up in tabular form-besides the guideline report-on the corresponding AWMF website for the S2k "Guideline for the medical clinical diagnostics of indoor mould exposure" ("Schimmelpilzexposition in Innenräumen, medizinisch klinische Diagnostik"; http://www.awmf.org/leitlinien/detail/ 1l/161-001.html).

Open Access This article is distributed under the terms of the Creative Commons Attribution 4.0 International License (http://creativecommons.org/licenses/by/4.0/), which permits unrestricted use, distribution, and reproduction in any medium, provided you give appropriate credit to the original author(s) and the source, provide a link to the Creative Commons license, and indicate if changes were made.

\section{References}

1. Wiesmüller GA, Heinzow B, Aurbach U, Bergmann K-C, Bufe A, Buzina W, Cornely OA. et al. Arbeitsgemenschaft der Wissenschaftlichen Medizinischen Fachgesellschaften. S2k-Leitlinie: Schimmelpilzexposition in Innenräumen, medizinisch klinische Diagnostik. 11 April 2016. http:// www.awmf.org/leitlinien/detail/ll/161-001.html. Last access: 13.01.2017.

2. Innenraumlufthygiene-Kommission des Umweltbundesamtes. Leitfaden zur Vorbeugung, Untersuchung, Bewertung und Sanierung von Schimmelpilzwachstum in Innenräumen ("Schimmelpilz-Leitfaden"). November 2002. http://www.umweltbundesamt.de/sites/default/ files/medien/publikation/long/4218.pdf. Last access: 13.01.2017.

3. Innenraumlufthygiene-Kommission des Umweltbundesamtes. Leitfaden zur Ursachensuche und Sanierung bei Schimmelpilzwachstum in Innenräumen ("Schimmelpilzsanierungs-Leitfaden”). Januar 2005. http:// www.umweltbundesamt.de/sites/default/files/medien/ publikation/long/4219.pdf. Last access: 13.01.2017.

4. Landesgesundheitsamt Baden-Württemberg. Schimmelpilze in Innenräumen - Nachweis, Bewertung, Qualitätsmanagement. Abgestimmtes Arbeitsergebnis des Arbeitskreises "Qualitätssicherung - Schimmelpilze in Innenräumen" am Landesgesundheitsamt Baden-Württemberg. 14 December 2001. http://www.anbus.de/lga. pdf, mit eingearbeitetem Addendum vom Dezember 2004. Last access: 13.01.2017.

5. Landesgesundheitsamt Baden-Württemberg. Handlungsempfehlung für die Sanierung von mit Schimmelpilzen befallenen Innenräumen. Juni 2006. http:// www.boa-bw.de/jspview/downloads/frei/bsz380042142/ 0/handlungsempfehlung schimmel.html. Last access: 13.01.2017.

6. Oswald R. Angemessene Antworten auf das komplexe Problem der Schimmelursachen? Stellungnahme zum DINFachbericht 4108-8 Vermeidung von Schimmelwachstum in Wohngebäuden. Bausachverstandige. 2011;7:32-7.

7. Institute of Medicine (IOM), Committee on Damp Indoor Spaces and Health, Board of Health Promotion and Disease Prevention. Damp indoor spaces and health. Washington, DC: National Academies Press; 2004. http://www.nap.edu/ openbook.php?record_id=11011.

8. Robert Koch-Institut, Kommission Methoden und Qualitätssicherung in der Umweltmedizin. Schimmelpilzbelastung in Innenräumen - Befunderhebung, gesundheitliche Bewertung und Maßnahmen. BundesgesundheitsblattGesundheitsforschung Gesundheitsschutz. 2007;50:1308-23.

9. WHO Regional Office for Europe. Guidelines for indoor air quality: dampness and mould. Kopenhagen: World Health Organization Europe; 2009. http://www.euro.who.int/_ data/assets/pdf_file/0017/43325/E92645.pdf?ua $=1$.

10. Wiesmüller GA, Heinzow B, Herr CEW. (editors) Gesundheitsrisiko Schimmelpilze im Innenraum. Landsberg: Ecomed Medizin; 2013.

11. Kommission für Krankenhaushygiene und Infektionsprävention (KRINKO) beim Robert Koch-Institut (RKI). Anforderungen an die Hygiene bei der medizinischen Versorgung von immunsupprimierten Patienten. Bundesgesundheitsblatt Gesundheitsforschung Gesundheitsschutz. 2010;53:357-88.

12. Haftenberger M, Laußmann D, Ellert U, Kalcklösch M, Langen U, Schlaud M, Schmitz R, Thamm M, Abteilung für Epidemiologie und Gesundheitsmonitoring, Robert Koch-Institut. Prävalenz von Sensibilisierungen gegen Inhalations- und Nahrungsmittelallergene. Ergebnisse der Studie zur Gesundheit Erwachsener in Deutschland (DEGS1). Bundesgesundheitsblatt Gesundheitsforschung Gesundheitsschutz. 2013;56:687-97.

13. Heinzerling LM, Burbach GJ, Edenharter G, Bachert C, Bindslev-Jensen C, Bonini S, et al. GA(2)LEN skin test study I: GA(2)LEN harmonization of skin prick testing: novel sensitization patterns for inhalant allergens in Europe. Allergy. 2009;64:1498-506.

14. Robert Koch-Institut, Kommission Methoden und Qualitätssicherung in der Umweltmedizin. Qualitätssicherung beim Lymphozytentransformationstest - Addendum zum LTT-Papier der RKI-Kommission ,Methoden und Qualitätssicherung in der Umweltmedizin'. BundesgesundheitsblattGesundheitsforschung Gesundheitsschutz. 2008;51:1070-6.

15. Anonymus. Schwerpunktthema Schimmelpilze. Umweltmed Hyg Arbeitsmed. 2010;15:69-112.

16. Anonymus. Schwerpunktthema: Schimmelpilze und allergische Erkrankungen. Umweltmed Hyg Arbeitsmed. 2011;16:61-108.

17. Anonymus. Schwerpunktthema: Schimmelpilze und toxische Reaktionen. Umweltmed Hyg Arbeitsmed. 2012;17:133-71.

18. Anonymus. Schwerpunktthema: Schimmelpilze und Geruchswirkungen, Befindlichkeitsstörungen. Umweltmed Hyg Arbeitsmed. 2013;1:5-40.

19. Sauni R, Uitti J, Jauhiainen M, Kreiss K, Sigsgaard T, VerbeekJH. Remediating buildings damaged by dampness and mould for preventing or reducing respiratory tract symptoms, infections and asthma (Review). Evid Based Child Health. 2013;8:944-1000. 
20. Palaty C, Shum M. Health effects from mould exposure or dampness in indoor environments (evidence review). Vancouver: National Collaborating Centre for Environmental Health; 2012. http://www.ncceh.ca/sites/default/files/ Mould_and_Health_Effects_Jul_2012.pdf.

21. Mendell MJ, Mirer AG, Cheung K, Tong M, Douwes J. Respiratory and allergic health effects of dampness, mold, and dampness-related agents: a review of the epidemiologic evidence. Environ Health Perspect. 2011;119:748-56.

22. Mücke W, Lemmen C. Schimmelpilze. In: Wichmann HE, Schlipköter HW, Fülgraff G, editors. Handbuch der Umweltmedizin. 30. Ergänzungslieferung. Landsberg: Ecomed; 2004.

23. Mücke W, Lemmen C. Schimmelpilze: Vorkommen - Gesundheitsgefahren - Schutzmaßnahmen, 3rd ed. Landsberg: Ecomed;2004.

24. Fischer G, Fischer G, Thißen R, Schmitz C, Dott W. Relevance of microfungi and their secondary metabolites (mycotoxins) for indoor hygiene. In: de Oliveira Fernandes E, Gameiro da Silva M, Rosado Pinto J, editors. Healthy Buildings 2006. Proceedings Vol. I - Indoor Air Quality (IAQ), building related diseases and human response 2006. pp. 189-94.

25. Bloom E, Grimsley LF, Pehrson C, Lewis J, Larsson L. Molds and mycotoxins in dust from water-damaged homes in New Orleans after hurricane Katrina. Indoor Air. 2009;19:153-8.

26. Fischer G, Thißen R, Müller T, Braun S, Dott W. Mikrobielle Stoffwechselprodukte als Meßparameter bei Emissionsbetrachtungen. Gefahrst Reinhalt Luft. 2004;64:229-38.

27. Pestka JJ, Yike I, Dearborn DG, Ward MD, Harkema JR. Stachybotrys chartarum, trichothecene mycotoxins, and damp building-related illness: new insights into a public health enigma. Toxicol Sci. 2008;104:4-26.

28. Mücke W, Lemmen C. Bioaerosole - Risiken durch biologische Luftinhaltsstoffe. Teil 1: Charakteristika von Bioaerosolen und Einzelkomponenten. Umweltmed Hyg Arbeitsmed. 2011;16:383-91.

29. Mücke W, Lemmen C. Bioaerosole - Risiken durch biologische Luftinhaltsstoffe. Teil 2: Expositionsermittlung bei Bioaerosolen. Umweltmed Hyg Arbeitsmed. 2012;17:35-45.

30. Mücke W, Lemmen C. Bioaerosole und Gesundheit: Wirkungen biologischer Luftinhaltsstoffe und praktische Konsequenzen. Landsberg: Ecomed Medizin; 2008.

31. Choi H, Byrne S, Larsen LS, Sigsgaard T, Thorne PS, Larsson L, et al. Residential culturable fungi, $(1-3,1-6)-\beta$-d-glucan, and ergosterol concentrations in dust are not associated with asthma, rhinitis, or eczema diagnoses in children. Indoor Air. 2014;24:158-70.

32. Frankel M, Hansen EW, Madsen AM. Effect of relative humidity on the aerosolization and total inflammatory potential of fungal particles from dust-inoculated gypsum boards. Indoor Air. 2014;24:16-28.

33. Górny RL, Reponen T, Willeke K, Schmechel D, Robine E, Boissier M, Grinshpun SA. Fungal fragments as indoor air biocontaminants. Appl Environ Microbiol. 2002;68:3522-31.

34. Hirvonen MR, Huttunen K, Roponen M. Bacterial strains from moldy buildings are highly potent inducers of inflammatory and cytotoxic effects. Indoor Air. 2005;15(Suppl 9):65-70.

35. Rao CY, Cox-Ganser JM, Chew GL, Doekes G, White S. Use of surrogate markers of biological agents in air and settled dust samples to evaluate a water-damaged hospital. Indoor Air. 2005;15(Suppl9):89-97.
36. Rylander R. Airborne ( $1 \rightarrow 3$ )-beta-d-Glucan and airway disease in a day-care center before and after renovation. Arch Environ Health. 1997;52:281-5.

37. Tischer CG, Heinrich J. Exposure assessment of residential mould, fungi and microbial components in relation to children's health: achievements and challenges. Int J Hyg Environ Health. 2013;216:109-14.

38. Kespohl S, Raulf M. Mould allergens: Where do we stand with molecular allergy diagnostics?: Part 13 of the series molecular allergology. Allergo J Int. 2014;23:120-5.

39. Rylander R. Microbial cell wall constituents in indoor air and their relation to disease. Indoor Air. 1998;8:59-68.

40. Fisk WJ, Lei-Gomez Q, Mendell MJ. Meta-analyses of the associations of respiratory health effects with dampness and mold in homes. Indoor Air. 2007;17:284-96.

41. Fisk WJ, Eliseeva EA, Mendell MJ. Association of residential dampness and mold with respiratory tract infections and bronchitis: a meta-analysis. Environ Health. 2010;9:72.

42. DiezU, von Mühlendahl KE. Inhalative Schimmelpilzbelastung. Leitlinie der Gesellschaft für PädiatrischeAllergologie und Umweltmedizin. Padiatr Allergol. 2005;1:38-9.

43. Bush RK, Portnoy JM, Saxon A, Terr AI, Wood RA. The medical effects of mold exposure. J Allergy Clin Immunol. 2006;117:326-33.

44. Seltzer JM, Fedoruk MJ. Health effects of mold in children. Pediatr Clin North Am. 2007;54:309-33.

45. Cox-Ganser JM, White SK, Jones R, Hilsbos K, Storey E, Enright PL, et al. Respiratory morbidity in office workers in a water-damaged building. Environ Health Perspect. 2005;113:485-90.

46. DalesR, RuestK, GuayM, MarroL, MillerJD. Residentialfungal growth and incidence of acute respiratory illness during the first two years of life. Environ Res. 2010;110:692-8.

47. Douwes J, Pearce N. Invited commentary: Is indoor mold exposure a risk factor for asthma? Am J Epidemiol. 2003;158:203-6.

48. Kuyucu S, Saraçlar Y, Tuncer A, Geyik PO, Adalioğlu G, Akpinarli A, et al. Epidemiologic characteristics of rhinitis in Turkish children: the International Study of Asthma and Allergies in Childhood (ISAAC) phase 2. Pediatr Allergy Immunol. 2006;17:269-77.

49. Mari A, Schneider P, Wally V, Breitenbach M, Simon-Nobbe B. Sensitization to fungi: epidemiology, comparative skin tests, and IgE reactivity of fungal extracts. Clin Exp Allergy. 2003;33:1429-38.

50. Reijula K, Leino M, Mussalo-Rauhamaa H, Nikulin M, Alenius H, Mikkola J, et al. IgE-mediated allergy to fungal allergens in Finland with special reference to Alternaria alternata and Cladosporium herbarum. Ann Allergy Asthma Immunol. 2003;91:280-7.

51. Torres-Rodriguez JM, Pulido-Marrero Z, Vera-Garcia Y. Respiratory allergy to fungi in Barcelona, Spain: clinical aspects, diagnosis and specific treatmentinageneralallergy unit. Allergol Immunopathol (Madr). 2012;40:295-300.

52. Jaakkola MS, Quansah R, Hugg TT, Heikkinen SA, Jaakkola $\mathrm{JJ}$. Association of indoor dampness and molds with rhinitis risk: a systematic review and meta-analysis. J Allergy Clin Immunol. 2013;132:1099-1110.e18.

53. Merget R. Allergische und nicht-allergische Erkrankungen der Lungen und Atemwege durch Schimmelpilze im Beruf. Umweltmed Hyg Arbeitsmed. 2001;16:95-7.

54. Fokkens WJ, Ebbens F, van Drunen CM. Fungus: a role in pathophysiology of chronic rhinosinusitis, disease modifier, a treatment target, or no role at all? Immunol Allergy Clin North Am. 2009;29:677-88.

55. Fokkens WJ, Lund VJ, Mullol J, Bachert C, Alobid I, Baroody F, et al. EPOS 2012: European position paper 
on rhinosinusitis and nasal polyps 2012. A summary for otorhinolaryngologists. Rhinology. 2012;50:1-12.

56. Green BJ, Beezhold DH, Gallinger Z, Barron CS, Melvin R, Bledsoe TA, et al. Allergic sensitization in Canadian chronic rhinosinusitis patients. Allergy Asthma Clin Immunol. 2014;10:15

57. Chakrabarti A, Denning DW, Ferguson BJ, Ponikau J, Buzina W, Kita H, et al. Fungal rhinosinusitis: a categorization and definitional schema addressing current controversies. Laryngoscope. 2009;119:1809-18.

58. Safirstein BH. Allergic bronchopulmonary aspergillosis with obstruction of the upper respiratory tract. Chest. 1976;70:788-90.

59. Schubert MS. Allergic fungal sinusitis: pathophysiology, diagnosis and management. Med Mycol. 2009;47(Suppl 1):S324-30.

60. Glass D, AmedeeRG. Allergic fungal rhinosinusitis: a review. Ochsner J. 2001;11:271-5.

61. Bent JP 3rd, Kuhn FA. Diagnosis of allergic fungal sinusitis. Otolaryngol Head NeckSurg. 1994;111:580-8.

62. Ebbens FA, Fokkens WJ. The mold conundrum in chronic rhinosinusitis: Where do we stand today? Curr Allergy Asthma Rep. 2008;8:93-101.

63. Fokkens WJ, van Drunen C, Georgalas C, Ebbens F. Role of fungi in pathogenesis of chronic rhinosinusitis: the hypothesis rejected. Curr Opin Otolaryngol Head Neck Surg. 2012;20:19-23.

64. Cohen M, Kofonow J, NayakJV, Palmer JN, Chiu AG, Leid JG, Cohen NA. Biofilms in chronic rhinosinusitis: a review. Am J Rhinol Allergy. 2009;23:255-60.

65. Foreman A, Psaltis AJ, Tan LW, WormaldPJ.Characterization of bacterial and fungal biofilms in chronic rhinosinusitis. Am J Rhinol Allergy. 2009;23:556-61.

66. Foreman A, Wormald PJ. Different biofilms, different disease? A clinical outcomes study. Laryngoscope. 2010;120:1701-6.

67. Keir J, Pedelty L, Swift AC. Biofilms in chronic rhinosinusitis: systematic review and suggestions for future research. JLaryngol Otol. 2011;125:331-7.

68. Reponen T, Lockey J, Bernstein DI, Vesper SJ, Levin L, Khurana Hershey GK, et al. Infant origins of childhood asthma associated with specific molds. J Allergy Clin Immunol. 2012;130:639-644.e5.

69. Hägerhed-Engman L, Sigsgaard T, Samuelson I, Sundell J, Janson S, Bornehag CG. Low home ventilation rate in combination with moldy odor from the building structure increase the risk for allergic symptoms in children. Indoor Air. 2009;19:184-92.

70. Iossifova YY, Reponen T, Ryan PH, Levin L, Bernstein DI, LockeyJE, et al. Mold exposure during infancy as a predictor of potential asthma development. Ann Allergy Asthma Immunol. 2009;102:131-7.

71. Pekkanen J, Hyvärinen A, Haverinen-Shaughnessy U, Korppi M, Putus T, Nevalainen A. Moisture damage and childhood asthma: a population-based incident casecontrol study. Eur Respir J.2007;29:509-15.

72. Tischer C, Chen CM, Heinrich J. Association between domestic mould and mould components, and asthma and allergy in children: a systematic review. Eur Respir J. 2011;38:812-24.

73. Halonen M, Stern DA, Wright AL, Taussig LM, Martinez FD. Alternaria as a major allergen for asthma in children raised in a desert environment. Am J Respir Crit Care Med. 1997;155:1356-61.

74. Licorish K, Novey HS, Kozak P, Fairshter RD, Wilson AF. Role of Alternaria and Penicillium spores in the pathogenesis of asthma. JAllergy Clin Immunol. 1985;76:819-25.
75. Meng J, Barnes CS, Rosenwasser LJ. Identity of the fungal species present in the homes of asthmatic children. Clin ExpAllergy. 2012;42:1448-58.

76. Schultze-Werninghaus G, Lévy J, Bergmann EM, Kappos $\mathrm{AD}$, Meier-Sydow J. Clinical significance of airborne Alternaria tenuis-spores: seasonal symptoms, positive skin and bronchial challenge tests with Alternaria in subjects with asthma and rhinitis. ExperientiaSuppl. 1987;51:153-6. doi:10.1007/978-3-0348-7491-5 27.

77. Zureik M, Neukirch C, Leynaert B, Liard R, Bousquet J, Neukirch F, European Community Respiratory Health Survey. Sensitization to airborne moulds and severity of asthma: cross-sectional study from European Community RespiratoryHealth Survey. BMJ. 2002;325:411-4.

78. Cazzoletti L, Marcon A, Corsico A, Janson C, Jarvis D, Pin I, et al. Asthma severity according to Global Initiative for Asthma and its determinants: an international study. Int Arch Allergy Immunol. 2010;151:70-9.

79. Malling HJ, Agrell B, Croner S, Dreborg S, Foucard T, Kjellman M, et al. Diagnosis and immunotherapy of mould allergy. I. Screening for mould allergy. Allergy. 1985;40:108-14.

80. Malling HJ. Diagnosis and immunotherapy of mould allergy. II. Reproducibility and relationship between skin sensitivity estimated by end-point titration and histamine equivalent reaction using skin prick tests and intradermal tests. Allergy. 1985;40:354-62.

81. Malling HJ, Dreborg S, Weeke B. Diagnosis and immunotherapy of mould allergy. III. Diagnosis of Cladosporium allergy by means of symptom score, bronchial provocation test, skin prick test, RAST, CRIE and histamine release. Allergy. 1986;41:57-67.

82. Malling HJ. Diagnosis and immunotherapy of mould allergy. IV. Relation between asthma symptoms, spore counts and diagnostic tests. Allergy. 1986;41:342-50.

83. Schultze-Werninghaus G. Allergische Atemwegs- und Lungenerkrankungen durch Schimmelpilze. In: Wiesmüller GA, Heinzow B, Herr CEW, editors. Gesundheitsrisiko Schimmelpilze im Innenraum. Landsberg: Ecomed; 2013. pp. 182-9.

84. Schultze-Werninghaus G, Lévy J, Bergmann EM, Kappos AD, Meier-Sydow J. Klinische Bedeutung von Sensibilisierungen gegen Alternaria tenuis bei Asthma bronchiale: Vergleich von Anamnese, Haut-und Provokationsproben mit Sporenhäufigkeit im Aeroplankton - eine retrospektive Analyse. Allergologie. 1986;9:525-31.

85. Bachert C, Kardoff B, Virchow C. (editors) Allergische Erkrankungen in der Praxis, 1sted. Bremen: Uni-Med; 1999.

86. Bachert C, Wiesmüller GA. Allergie und Umwelt. Bremen: Uni-Med;2002.

87. Merk HF (editor) Allergologie - Textbuch und Farbatlas. Berlin: Blackwell; 1998. Engled: Mygind N, DahlR, Pedersen S, Thestrup-Pedersen Ketal. (editors). Allergology.

88. Ring J. (editor) Neurodermitis. Expertise zur gesundheitlichen Versorgung und Vorsorge bei Kindern mit atopischem Ekzem. Landsberg: Ecomed; 1998.

89. Steiß JO, Lindemann H, Brosig B, Zimmer KP. Wichtige Aspekte bei der Betreuung chronisch kranker Kinder und Jugendlicher am Beispiel des Asthma bronchiale. Dtsch MedWochenschr. 2013;138:2613-8.

90. Kersten W, von Wahl PG. Schimmelpilzallergie. Klinische Untersuchungsergebnisse. Allergologie. 1989;12:174-8.

91. Iversen M, Dahl R. Characteristics of mold allergy. J Investig Allergol Clin Immunol. 1995;5:205-8.

92. Tarlo SM, Fradkin A, Tobin RS. Skin testing with extracts of fungal species derived from the homes of allergy clinic patients in Toronto. Canada Clin Allergy. 1988;18:45-52. 
93. Rylander R, Persson K, Goto H, Yuasa K, Tanaka S. Airborne beta-1,3-glucan may be related to symptoms in sick buildings. Indoor BuiltEnviron. 1992;1:263-7.

94. Rylander R, Norrhall M, Engdahl U, Tunsäter A, Holt PG. Airways inflammation, atopy and $(1 \rightarrow 3)$-beta-D-glucan exposures in two schools. Am J Respir Crit Care Med. 1998;158:1685-7.

95. Maes MFJ, van Baar HM, van Ginkel CJ. Occupational allergic contact dermatitis from the mushroom White Pom Pom (Hericium erinaceum). ContactDerm. 1999;40:289-90.

96. Hoff M, Trüeb RM, Ballmer-Weber BK, Vieths S, Wuethrich B. Immediate-type hypersensitivity reaction to ingestion of mycoprotein (Quorn) in a patient allergic to molds caused by acidic ribosomal protein P2. J Allergy Clin Immunol. 2003;111:1106-10.

97. Maibach HI. Contact urticaria syndrome from mold on salami casing. Contact Derm. 1995;32:120-1.

98. Morisset M, Parisot L, Kanny G, Moneret-Vautrin DA. Food allergy to moulds: two cases observed after dry fermented sausage ingestion. Allergy. 2003;58:1203-4.

99. Shelly WB, Florence R. Chronic urticaria due to mold hypersensitivity. A study in cross sensitization and autoerythrocyte sensitization. Arch Dermatol. 1961;83:549-58.

100. Griese M, Haug M, Hartl D, Teusch V, Glöckner-Pagel J, Brasch F, National EAA Study Group. Hypersensitivity pneumonitis: lessons for diagnosis and treatment of a rare entity in children. Orphanet J Rare Dis. 2013;8:121.

101. Rolke M, Rumpf J, Kroidl R, Sennekamp J. Neue epidemiologische Daten zur exogen-allergischen Alveolitis in Deutschland. Allergologie. 2006;29:439-42.

102. Dott W, Fischer G, Müller T, Thißen R, Wiesmüller GA. Belastung der Arbeitnehmer bei Schimmelpilzsanierungsarbeiten in Innenräumen - Literaturstudie. Tiefbau-Berufsgenossenschaft München (AZ 612.17TB12 AK Gebäudesanierung). Mai 2004. http://www.bgbau.de/koop/ forschung/downloads/sp-literaturstudie.pdf. Last access: 13.01.2017.

103. Müller-Wening D. Klinik der exogen-allergischen Alveolitis. Allergologie. 1990;13:91-103.

104. Sennekamp J. Kap. IV-5.3.2: Exogen-allergische Alveolitis. In: Konietzko J, Dupuis H, editors. Handbuch der Arbeitsmedizin. Landsberg: Ecomed; 1989.

105. Mücke W, Lemmen C. Bioaerosole - Risiken durch biologische Luftinhaltsstoffe. Teil 3: Allergien und Infektionen durch Bioaerosole. Umweltmed Hyg Arbeitsmed. 2012;17:104-13.

106. Sennekamp J. Exogen-allergische Alveolitis. In: Letzel S, Nowak D, editors. Handbuch der Arbeitsmedizin. Landsberg: Ecomed; 2007. pp. 1-62.

107. Nowak D, Angerer A. Exogen-allergische Alveolitis. In: Triebig G, Kentner M, Schulz R, editors. Arbeitsmedizin. Handbuch für Theorie und Praxis. Stuttgart: Gentner; 2002.

108. Apostolakos MJ, Rossmoore H, Beckett WS. Hypersensitivity pneumonitis from ordinary residential exposures. Environ Health Perspect. 2001;109:979-81.

109. Engelhart S, Rietschel E, Exner M, Lange L. Childhood hypersensitivity pneumonitis associated with fungal contamination of indoor hydroponics. Int J Hyg Environ Health. 2009;212:18-20.

110. Thörn A, Lewné M, Belin L. Allergic alveolitis in a school environment. Scand JWorkEnviron Health. 1996;22:311-4.

111. Trout D, Bernstein J, Martinez K, Biagini R, Wallingford K. Bioaerosol lung damage in a worker with repeated exposure to fungi in a water-damaged building. Environ Health Perspect. 2001;109:641-4.

112. Sennekamp J, Müller-Wening D, Amthor M, Baur X, Bergmann KC, Costabel U, et al. Empfehlungen zur
Diagnostik der exogen-allergischen Alveolitis. 13. Tagung der Arbeitsgemeinschaft exogen-allergische Alveolitis der Deutschen Gesellschaft für Pneumologie und Beatmungsmedizin (DGP) und der Deutschen Gesellschaft für Allergologie und Klinische Immunologie (DGAKI). Allergologie. 2006;29:431-8.

113. Sennekamp J, Müller-Wening D, Amthor M, Baur X, Bergmann KC, Costabel U, et al. Empfehlungen zur Diagnostik der exogen-allergischen Alveolitis der Arbeitsgemeinschaft exogen-allergische Alveolitis der Deutschen Gesellschaft für Pneumologie und Beatmungsmedizin e. V. (DGP) und der Deutschen Gesellschaft für Allergologie und Klinische Immunologie (DGAKI). Pneumologie. 2007;61:52-6.

114. Universitätsklinikum Giessen und Marburg. Exogen allergische Alveolitis 2015. http://www.ukgm.de/ugm_2/ deu/ugi_pne/8023.html. Last access: 13.01.2017.

115. Rosenberg M, Patterson R, Mintzer R, Cooper BJ, Roberts $\mathrm{M}$, Harris KE. Clinical and immunologic criteria for the diagnosis of allergic bronchopulmonary aspergillosis. Ann Intern Med. 1977;86:405-14.

116. Huttegger I, Crameri R, Eichler I, Müller FM, Lindemann H, Griese M. Die allergisch-bronchopulmonale Aspergillose bei zystischer Fibrose. Monatsschr Kinderheilkd. 2006;154:1003-14.

117. Köhler D, Schönhofer B, Voshaar T. Pneumologie: Ein Leitfaden für rationales Handeln in Klinik und Praxis, 2nd ed. Stuttgart: Thieme; 2015.

118. Kroegel C, Costabel U. Klinische Pneumologie, 1st ed. Stuttgart: Thieme; 2014.

119. Menz G, Cramer R, Hense G. Die allergische bronchopulmonale Aspergillose (ABPA). Allergologie. 2005;28:315-22.

120. Steiß JO, Lindemann $\mathrm{H}$. Allergische bronchopulmonale Aspergillose bei zystischer Fibrose. Allergologie. 2013;36:275-81.

121. Heinz WJ. Welche Bedeutung haben Infektionen durch Schimmelpilze? Umweltmed Hyg Arbeitsmed. 2010;2:99-103.

122. Rüping MJTG, Vehreschild JJ, Beisel C, Müller C, Fischer G, Wickenhauser C, et al. Fungiscope - a global rare fungal infection registry. Onkologie. 2008;31(Suppl4):V656.

123. Anonymous. Aspergilloma and residual tuberculous cavities-theresults of a resurvey. Tubercle. 1970;51:227-45.

124. Sonnenberg P, Murray J, Glynn JR, Shearer S, Kambashi B, Godfrey-Faussett P. HIV-1 and recurrence, relapse, and reinfection of tuberculosis after cure: a cohort study in South African mineworkers. Lancet. 2001;358:1687-93.

125. Guinea J, Torres-Narbona M, Gijon P, MuñozP, Pozo F, Peláez $\mathrm{T}$, et al. Pulmonary aspergillosis in patients with chronic obstructive pulmonary disease: incidence, risk factors, and outcome. Clin Microbiol Infect. 2010;16:870-7.

126. He HY, Chang S, Ding L, Sun B, Li F, Zhan QY. Significance of Aspergillus spp. isolation from lower respiratory tract samples for the diagnosis and prognosis of invasive pulmonary aspergillosis in chronic obstructive pulmonary disease. Chin Med J. 2012;125:2973-8.

127. Fischer G. Infektiologisch relevante Fadenpilze. In: Wiesmüller GA, Heinzow B, Herr CEW, editors. Gesundheitsrisiko Schimmelpilze im Innenraum. Landsberg: Ecomed; 2013. pp.51-62.

128. Abek D, Gruseck E, Korting HC, Ring J. Onychomykose: Epidemiologie, Pathogenese, Klinik, Mikrobiologie und Therapie. Dtsch Arztebl. 1996;93:A:2027-32.

129. Abek D, Haneke E, Nolting S, Reinel D, Seebacher C. Onychomykose. Aktuelle Daten zu Epidemiologie, Erregerspektrum, Risikofaktoren sowie Beeinflussung der Lebensqualität. Dtsch Arztebl. 2000;97:A:1984-6. 
130. Mayser P, Gründer K. Das Erregerspektrum der Onychomykosen in der Universitäts-Hautklinik Giessen 1987-1992 und dessen potenzielle Bedeutung für eine antimykotische Therapie. ZHautkr. 1993;68:716-21.

131. Nenoff P. Dermatomykosen durch Schimmelpilze - 16. Tagung der Arbeitsgemeinschaft ,Mykologische Laboratoriumsdiagnostik' der Deutschsprachigen Mykologischen Gesellschaft (DMykG). Mikrobiologe. 2005;2:75-7.

132. Ramani R, Srinivas CR, Ramani A, Kumari TG, Shivananda PG. Molds in onychomycosis. Int J Dermatol. 1993;32:877-8.

133. Torres-Rodriguez JM, Madrenys-Brunet N, Siddat M, López-Jodra O, Jimenez T. Aspergillus versicolor as cause of onychomycosis: report of 12 cases and susceptibility testing of antifungal drugs. J Eur Acad Dermatol Venereol. 1998;11:25-31.

134. Benoit D, Peleman R, Claeys G, Hertveldt K, Vandewoude K. Mixed community-acquired fungal infection in an apparently healthy patient. Eur J Clin Microbiol Infect Dis. 2000;19:642-3.

135. Chen KY, Ko SC, Hsueh PR, Luh KT, YangPC. Pulmonary fungal infection: emphasis on microbiological spectra, patient outcome, and prognostic factors. Chest. 2001;120:177-84.

136. Clancy CJ, Nguyen MH. Acute community-acquired pneumonia due to Aspergillus in presumably immunocompetent hosts: clues for recognition of a rare but fatal disease. Chest. 1998;114:629-34.

137. Staib F, Abel T, Mishra SK, Müller JA. Aspergillus-fumigatusInfektion der Lunge bei Mucoviscidose: Beitrag zur Diagnostik, Epidemiologie, Pathogenese und Prophylaxe. Dtsch Med Wochenschr. 1980;105:442-5.

138. Vandenbos F, Hyvernat H, Tamisier R, Bernard E, GariToussaint M, Mattei M. Pleuropneumopathie communautaire a Aspergillus fumigatus chez une patiente peu immunodeprimée. Rev Med Interne. 2001;22:1130-2.

139. Vonberg RP, Gastmeier P. Aspergillen im Krankenhaus: Ergebnisse von Outbreak-Analysen. Krankenhaushyg Infektionsverhut. 2007;29:8-14.

140. Fernández-Ruiz M, Silva JT, San-Juan R, de Dios B, García-Luján R, López-Medrano F, et al. Aspergillus tracheobronchitis: report of 8 cases and review of the literature. Medicine (Baltimore). 2012;91:261-73.

141. Hope WW, Walsh TJ, Denning DW. The invasive and saprophytic syndromes due to Aspergillus spp. Med Mycol. 2005;43(Suppl 1):S207-S238.

142. Brown GD, Denning DW, Gow NA, Levitz SM, Netea MG, White TC. Hidden killers: human fungal infections. Sci Transl Med. 2012;4:165rv13.

143. Latgé JP. Aspergillus fumigatus and aspergillosis. Clin Microbiol Rev. 1999;12:310-50.

144. Patterson TF, Thompson GR 3rd, Denning DW, Fishman JA, Hadley S, Herbrecht R, et al. Practice guidelines for the diagnosis and management of aspergillosis: 2016 update by the Infectious Diseases Society of America. Clin Infect Dis. 2016;63:e1-e60.

145. Sennekamp J. Differentialdiagnose Organic Dust Toxic Syndrome (ODTS) - exogen-allergischeAlveolitis. Allergologie. 1996;19:111-3.

146. Herr C, Bittighofer PM, Bunger J, Eikmann T, Fischer AB, Gruner C, et al. Effect of microbial aerosols on the human. Schriftenr Ver Wasser Boden Lufthyg. 1999;104:403-81.

147. Malmberg P, Rask-Andersen A, Rosenhall L. Exposure to microorganisms associated with allergic alveolitis and febrile reactions to mold dust in farmers. Chest. 1993;103:1202-9.
148. Rylander R. Organic dusts and lung reactions - exposure characteristics and mechanisms for disease. Scand J Work Environ Health. 1985;11:199-206.

149. Centers for Disease Control and Prevention (CDC). Availability of case definition for acute idiopathic pulmonary hemorrhage in infants. MMWR Morb Mortal Wkly Rep. 2001;50:494-5.

150. Mazur LJ, Kim J, Committee on Environmental Health, American Academy of Pediatrics. Spectrum of noninfectious health effects from molds. Pediatrics. 2006;118:e1909-e1926.

151. Dearborn DG. Chapter 38: mold. In: Landrigan PJ, Etzel RA, editors. Textbook of children's environmental health. Oxford: Oxford University Press; 2014.

152. Committee on Environmental Health, American Academy of Pediatrics, Kim JJ, Mazur LJ. Spectrum of nonifectious health effects from molds. Pediatrics. 2006;118:2582-6.

153. Stark PC, Burge HA, Ryan LM, Milton DK, Gold DR. Fungal levels in the homeand lower respiratory tract illnesses in the first year of life. Am J Respir Crit Care Med. 2003;168:232-7.

154. Mendell MJ, Cozen M, Lei-Gomez Q, Brightman HS, Erdmann CA, Girman JR, Womble SE. Indicators of moisture and ventilation system contamination in U.S. office buildings as risk factors for respiratory and mucous membrane symptoms: analyses of the EPA BASE data. JOccup Environ Hyg. 2006;3:225-33.

155. Ebbehøj NE, Meyer HW, Würtz H, Suadicani P, Valbjørn $\mathrm{O}$, Sigsgaard T, et al. Molds in floor dust, building-related symptoms, and lung function among male and female schoolteachers. Indoor Air. 2005;15(Suppl 10):7-16.

156. Baser S, Fisekci FE, Ozkurt S, Zencir M. Respiratory effects of chronic animal feed dust exposure. J Occup Health. 2003;45:324-30.

157. Bascom R. The upper respiratory tract: mucous membrane irritation. Environ Health Perspect. 1991;95:39-44.

158. Rudblad S, Andersson K, Bodin L, Stridh G, Juto JE. Nasal mucosal histamine reactivity among teachers sixyears after working in a moisture-damaged school. Scand J Work Environ Health. 2005;31:52-8.

159. Herr CE,Zur Nieden A, Jankofsky M, Stilianakis NI, Boedeker RH, Eikmann TF. Effects of bioaerosol polluted outdoor air on airways of residents: a cross sectional study. Occup Environ Med. 2003;60:336-42.

160. Radon K, Danuser B, Iversen M, Jörres R, Monso E, Opravil $\mathrm{U}$, etal. Respiratory symptoms in European animal farmers. Eur Respir J.2001;17:747-54.

161. Reijula K. Exposure to microrganisms: diseases and diagnosis. Indoor Air. 1998;8(S4):40-4.

162. Storey E, Dangman KH, Schenck P, DeBernardo RL, Yang CS, Bracker A, Hodgson MJ. Guidance for clinicians on the recognition and management of health effects related to mold exposure and moisture indoors. University of Connecticut Health Center, Division of Occupational and Environmental Medicine, Center for Indoor Environments and Health. September 2004. http://health.uconn.edu/ occupational-environmental/wp-content/uploads/sites/ 25/2015/12/mold_guide.pdf.

163. Douwes J, van der Sluis B, Doekes G, van Leusden F, Wijnands L, van Strien R, et al. Fungal extracellular polysaccharides in house dust as a marker for exposure to fungi: relations with culturable fungi, reported home dampness, and respiratory symptoms. J Allergy Clin Immunol. 1999;103:494-500.

164. Douwes J, Zuidhof A, Doekes G, van der Zee SC, Wouters I, Boezen MH, Brunekreef B. $(1 \rightarrow 3)$-beta-D-glucan and endotoxin in house dust and peak variability in children. AmJ Respir Crit Care Med. 2000;162:1348-54. 
165. Johannessen LN, Nilsen AM, Løvik M. The mycotoxins citrinin and gliotoxin differentially affect production of the pro-inflammatory cytokines tumour necrosis factor-alpha and interleukin-6, and the anti-inflammatory cytokine interleukin-10. Clin Exp Allergy. 2005;35:782-9.

166. Taskar V, Coultas D. Exposures and idiopathic lung disease. Semin Respir CritCare Med. 2008;29:670-9.

167. Terčelj M, Salobir B, Zupancic M, Wraber B, Rylander R. Inflammatory markers and pulmonary granuloma infiltration in sarcoidosis. Respirology. 2014;19:225-30.

168. Hodgson MJ, Flannigan B. Occupational respiratory disease: hypersensitivity pneumonitis and other forms of interstitial lung disease. In: Flannigan B, Samson RA, Miller JD, editors. Microorganisms in home and indoor work environments: diversity, health impacts, investigation and control, 2nd edn. London: CRCPress; 2011.

169. Laney AS, Cragin LA, Blevins LZ, Sumner AD, Cox-Ganser JM, Kreiss K, et al. Sarcoidosis, asthma, and asthmalike symptoms among occupants of a historically waterdamaged office building. Indoor Air. 2009;19:83-90.

170. Centers for Disease Control and Prevention (CDC), National Institute for Occupational Safety and Health (NIOSH). Letter to Vermont Department of Health (VDH) 2008. http://healthvermont.gov/local/documents/ NIOSHltrtoVSEA010208.pdf.

171. Newman LS, Rose CS, Maier LA. Sarcoidosis. N Engl J Med. 1997;336:1224-34.

172. Ortiz C, Hodgson MJ, McNally D, Storey E. A case-control study of sarcoidosis. In: Johanning E, editor. Bioaerosols, fungi and mycotoxins: health effects, assessment, prevention and control. Albany: Eastern New York Occupational and Environmental Health Center; 1999. pp. 476-81.

173. Rybicki BA, Major M, Popovich J Jr, Maliarik MJ, Iannuzzi MC. Racial differences in sarcoidosis incidence: a 5year study in a health maintenance organization. Am J Epidemiol. 1997;145:234-41.

174. Lorenz W, Buhrmann C, Mobasheri A, Lueders C, Shakibaei M. Bacterial lipopolysaccharides form procollagenendotoxin complexes that trigger cartilage inflammation and degeneration: implications for the development of rheumatoid arthritis. Arthritis Res Ther. 2013;15:R111.

175. Luosujärvi RA, Husman TM, Seuri M, Pietikäinen MA, Pollari P, Pelkonen J, et al. Joint symptoms and diseases associated with moisture damage in a health center. Clin Rheumatol. 2003;22:381-5.

176. Myllykangas-LuosujärviR, SeuriM,Husman T, KorhonenR, Pakkala K, Aho K. A cluster of inflammatory rheumatic diseases in a moisture-damaged office. Clin Exp Rheumatol. 2002;20:833-6.

177. Nevalainen A, Seuri M. Of microbes and men. Indoor Air. 2005;15(Suppl9):58-64.

178. Sagunski H. Mikrobielle flüchtige organische Verbindungen: Expositionsindikatoren bei Schimmelpilzbefall in Innenräumen? Umweltmed Hyg Arbeitsmed. 1997;2:95-100.

179. Macher J. Bioaerosols: assessment and control. Cincinnati: American Conference of Governmental Industrial Hygienists (ACGIH); 1999.

180. Pluschke P. Indoor air pollution. The handbook of environmental chemistry. vol 4. Heidelberg: Springer; 2004.

181. Schleibinger H, Laußmann D, Eis D, Samwer H, Rüden H. Sind MVOC geeignete Indikatoren für einen verdeckten Schimmelpilzbefall? Umweltmed Hyg Arbeitsmed. 2004;9:151-61.

182. Heinzow B, Walker G. Gesundheitliche Bedeutung der MVOC. In: Wiesmüller GA, Heinzow B, Herr CEW, edi- tors. Gesundheitsrisiko Schimmelpilze im Innenraum. Landsberg: Ecomed;2013. pp. 241-60.

183. KorpiA, JärnbergJ, PasanenAL. The Nordic Expert Groupfor Criteria Documentation of Health Risks from Chemicals. 138. Microbial volatile organic compounds (MVOCs). Arbete och Hälsa (Work and Health). Stockholm: National Institute for Working Life; 2006. http:/ / www.inchem.org/ documents/kemi/kemi/ah2006_13.pdf.

184. Korpi A, Järnberg J, Pasanen AL. Microbial volatile organic compounds. Crit RevToxicol. 2009;39:139-93.

185. Mücke W, Lemmen C. Duft und Geruch: Wirkungen und gesundheitliche Bedeutung von Geruchsstoffen. Landsberg: Ecomed; 2010.

186. Dalton P, Hummel T. Chemosensory function and response in idiopathic environmental intolerance. Occup Med. 2000;15:539-56.

187. Bullinger M. Befindlichkeitsstörungen. In: Wichmann HE, Schlipköter HW, Füllgraf G, editors. Handbuch der Umweltmedizin. Landsberg: Ecomed; 1992. pp. 1-12.

188. Bullinger M. Befindlichkeitsstörungen. In: DottW, MerkHF, Neuser J, Osieka R, editors. Lehrbuch der Umweltmedizin: Grundlagen-Untersuchungsmethoden-Krankheitsbilder - Prävention. Stuttgart: Wissenschaftliche Verlagsgesellschaft; 2002. pp. 494-500.

189. Wiesmüller GA, Heinzow B, Herr CEW. Befindlichkeitsstörungen in Innenräumen. Umweltmed Hyg Arbeitsmed. 2013;18:30-4.

190. Chapman JA, Terr AI, Jacobs RL, Charlesworth EN, Bardana EJ Jr. Toxic mold: phantom risk vs science. Ann Allergy Asthma Immunol. 2003;91:222-32.

191. Khalili B, Montanaro MT, Bardana EJ Jr. Inhalational mold toxicity: fact or fiction? A clinical review of 50 cases. Ann Allergy Asthma Immunol. 2005;95:239-46.

192. Lees-HaleyPR. Toxic mold and mycotoxins in neurotoxicity cases: Stachybotrys, Fusarium, Trichoderma, Aspergillus, Penicillium, Cladosporium, Alternaria, Trichothecenes. Psychol Rep. 2003;93:561-84.

193. Terr AI. Sick Building Syndrome: Is mould the cause? Med Mycol. 2009;47(Suppl 1):S217-S222.

194. Gordon WA, Cantor JB, Johanning E, Charatz HJ, Ashman TA, Breeze JL, et al. Cognitive impairment associated with toxigenic fungal exposure: a replication and extension of previous findings. Appl Neuropsychol. 2004;11:65-74.

195. BundesanstaltfürArbeitsschutzund Arbeitsmedizin. Technische Regel für Biologische Arbeitsstoffe 460: Einstufung von Pilzen in Risikogruppen (TRBA 460). Bundesarbeitsblatt. 2002;10:78-84, GMBl2016;29-30:562.

196. Bundesregierung. Biostoffverordnung-Verordnung über Sicherheit und Gesundheitsschutz bei Tätigkeiten mit Biologischen Arbeitsstoffen (BioStoffV). Bundesgesetzblatt. 2013;40:2514-34

197. Lindemann H, Tümmler B, Dockter G. (editors) Mukoviszidose - Zystische Fibrose, 4th ed. Stuttgart: Thieme; 2004.

198. Raad I, Tarrand J, Hanna H, Albitar M, Janssen E, Boktour M, et al. Epidemiology, molecular mycology, and environmental sources of Fusarium infection in patients with cancer. Infect Control Hosp Epidemiol. 2002;23:532-7.

199. Nagano Y, Millar BC, Johnson E, Goldsmith CE, Elborn JS, Rendall J, et al. Fungal infections in patients with cystic fibrosis. Rev Med Microbiol. 2007;18:11-6.

200. Gabrio T, Weidner U. Vorkommen und gesundheitliche/ allergologische Relevanz von Schimmelpilzen aus Sicht der Umweltmedizin. Allergologie. 2010;33:101-8.

201. Zöllner IK, Weiland SK, Piechotowski I, Gabrio T, von Mutius E, Link B, Pfaff G, et al. No increase in the prevalence of 
asthma, allergies, and atopic sensitisation among children in Germany: 1992-2001. Thorax. 2005;60:545-8.

202. Immonen J, Meklin T, Taskinen T, Nevalainen A, Korppi M. Skin-prick test findings in students from moisture- and mould-damaged schools: a 3-year follow-up study. Pediatr Allergy Immunol. 2001;12:87-94.

203. Taskinen T, Meklin T, Nousiainen M, Husman T, Nevalainen A, Korppi M. Moisture and mould problems in schools and respiratory manifestations in schoolchildren: clinical and skin test findings. Acta Paediatr. 1997;86:1181-7.

204. Taskinen T, Hyvärinen A, Meklin T, Husman T, Nevalainen A, Korppi M. Asthma and respiratory infections in school children with special reference to moisture and mold problems in the school. Acta Paediatr. 1999;88:1373-9.

205. ZahradnikE, KespohlS, Sander I, Schies U, Khosravie-Hohn J, Lorenz W, et al. A new immunoassay to quantify fungal antigens from the indoor mould Aspergillus versicolor. Environ Sci Process Impacts. 2013;15:1162-71.

206. Park JH, Kreiss K, Cox-Ganser JM. Rhinosinusitis and mold as risk factors for asthma symptoms in occupants of a waterdamaged building. Indoor Air. 2012;22:396-404.

207. Karvonen AM, Hyvärinen A, Korppi M, Haverinen-Shaughnessy U, Renz H, Pfefferle PI, et al. Moisture damage and asthma: a birth cohort study. Pediatrics. 2015;135:e598-e606.

208. Page E, Trout D. Mycotoxins and building-related illness. JOccup Environ Med. 1998;40:761-4.

209. Wiesmüller GA, Szewzyk R, Baschien C, Gabrio T, Fischer G, Grün L, Heinzow B, et al. Häufige Fragestellungen in Zusammenhang mit der Bewertung eines möglichen Geruchswirkungen und Befindlichkeitsstörungen Schimmelpilzexpositionen: Antworten eines Round Table auf dem Workshop "Schimmelpilze-Geruchswirkungen und Befindlichkeitsstörungen” im Rahmen der GHUP-Jahrestagung 2012. Umweltmed Hyg Arbeitsmed. 2013;18:35-40.

210. Gross R. Die Anamnese in der Sicht des Klinikers. In: Heite HJ, editor. Anamnese - Methoden der Erfassung und Auswertung anamnestischer Daten. Interviewtechnik, Fragebogenkonstruktion, Mensch-Maschinen-Dialog. Stuttgart: Schattauer; 1971. pp. 17-28.

211. Loidolt D, Gailhofer G, Pongratz M, Ludvan M, Ginter G. Interdisziplinäre Betrachtung zum Thema "Pilzsporenallergie". Allergologie. 1989;12:427-31.

212. Wiesmüller GA, Gabrio T. Möglichkeiten und Grenzen der gesundheitlichen Bewertung von Schimmelpilzexpositionen im Innenraum. Gefahrst Reinhalt Luft. 2014;74:391-5.

213. Gabrio T, Herr C, Hurraß J, Raulf M, Wiesmüller GA. Untersuchungsmethoden zur Erfassung einer Schimmelpilzexposition - ein Update. Umweltmed Hyg Arbeitsmed. 2015;20:115-31.

214. Department of Health and Human Services, Centers for Disease Control and Prevention, National Institute for Occupational Safety and Health. Preventing occupational respiratory disease from exposures caused by dampness in office buildings, schools, and other nonindustrial buildings. Cincinnati: DHHS (NIOSH); 2012. http: / www. cdc.gov/niosh/docs/2013-102/pdfs/2013-102.pdf.

215. Hinke M, Seibert M. (editors) Pilze in Innenräumen und am Arbeitsplatz. Wien: Springer; 2013

216. Steiß JO, Lindemann H. Pathophysiologische und diagnostische Prinzipien bei Allergien. In: Lindemann $\mathrm{H}$, Steiß JO, editors. Praxis der pädiatrischen Allergologie und Pneumologie. München: Dustri; 2006. pp. 1-13.

217. Steiß JO. Asthma bronchiale und Schimmelpilzbelastung im Kindes- und Jugendalter. In: Wiesmüller GA, Heinzow B, Herr CEW, editors. Gesundheitsrisiko Schimmelpilze im Innenraum. Landsberg: Ecomed;2013. pp. 146-55.
218. Raulf M. Diagnostik der Allergien vom Soforttyp - "State of the Art". Akt Dermatol. 2009;35:385-92.

219. van Kampen V, Rabstein S, Sander I, Merget R, Brüning T, Broding HC, et al. Prediction of challenge test results by flour-specific IgE and skin prick test in symptomatic bakers. Allergy. 2008;63:897-902.

220. Mayo Clinic, Mayo Medical Laboratories. Test ID: ASPAG - Aspergillus (Galactomannan) antigen, serum 2016. http://www.mayomedicallaboratories.com/test-catalog/ Clinical+and+Interpretive/84356. Lastaccess: 13.01.2017.

221. Fontana C, Gaziano R, Favaro M, Casalinuovo IA, Pistoia E, Di Francesco P. (1-3)- $\beta$-D-glucan vs Galactomannan antigen in diagnosing Invasive Fungal Infections (IFIs). Open Microbiol J. 2012;6:70-3.

222. Gonsior E, Henzgen M, Jörres RA, Kroidl RF, Merget $\mathrm{R}$, Riffelmann FW, et al. Guidelines for conducting provocation tests with allergens. German Society of Allergology and Clinical Immunology and German Society for Immunology. Pneumologie. 2002;56:187-98.

223. Kespohl S, Maryska S, Zahradnik E, Sander I, Brüning T, Raulf-Heimsoth M. Biochemical and immunological analysis of mould skin prick test solution: current status of standardization. Clin Exp Allergy. 2013;43:1286-96.

224. Saloga J, Klimek L, Buhl R, Mann W, Knop J, Grabbe S. (editors) Allergologie-Handbuch: Grundlagen und klinische Praxis. Stuttgart: Schattauer;2011.

225. AlbeggerK. Diagnosis of allergic rhinitis. I.Anamnesis-ENT medical examination - skin tests - intranasal provocation. HNO. 1991;39:77-81.

226. Bachert C. Reproducibility of the intranasal provocation test. Laryngol Rhinol Otol (Stuttg). 1987;66:157-60.

227. Gosepath J, Amedee RG, Mann WJ. Nasal provocation testing as an international standard for evaluation of allergic and nonallergic rhinitis. Laryngoscope. 2005;115:512-6.

228. Riechelmann H, Bachert C, Goldschmidt O, Hauswald B, Klimek L, Schlenter WW, et al. Durchführung des nasalen Provokationstests beiErkrankungen der oberen Atemwege. Allergo J.2002;11:29-36.

229. Gronemeyer U. Der konjunktivale Provokationstest. In: Schulze-Werninghaus G, Fuchs T, Bachert C, Wahn U, editors. Manuale allergologicum. München: Dustri; 2004. pp. 579-82.

230. Karvala K, Toskala E, Luukkonen R, Lappalainen S, Uitti J, Nordman $\mathrm{H}$. New-onset adult asthma in relation to damp and moldy workplaces. Int Arch Occup Environ Health. 2010;83:855-65.

231. Burkhard B. Unkonventionelle Konzepte in der Umweltmedizin. Versicherungsmedizin. 1996;48:179-84.

232. Eis D. Clinical ecology - an unproved approach in the context of environmental medicine. Zentralbl Hyg Umweltmed. 1999;202:291-330.

233. Oepen I. Unkonventionelle diagnostische und therapeutische Methoden in der Umweltmedizin. Gesundheitswesen. 1998;60:420-30.

234. Brehler R, Klimek L, Kopp MV, Virchow JC. Specific immunotherapy-indications and mode of action. Dtsch Arztebl Int. 2013;110:148-58.

235. Pfaar O, Bachert C, Bufe A, Buhl R, Ebner C, Eng P, Friedrichs $\mathrm{F}$, et al. Guideline on allergen-specific immunotherapy in IgE-mediated allergic diseases: S2k Guideline of the German Society for Allergology and Clinical Immunology (DGAKI), the Society for Pediatric Allergy and Environmental Medicine (GPA), the Medical Association of German Allergologists (AeDA), the Austrian Society for Allergy and Immunology (ÖGAI), the Swiss Society for Allergy and Immunology (SGAI), the German Society of Dermatology (DDG), the German Society of Oto-Rhino-Laryngology, 
Head and Neck Surgery (DGHNO-KHC), the German Society of Pediatrics and Adolescent Medicine (DGKJ), the Society for Pediatric Pneumology (GPP), the German Respiratory Society (DGP), the German Association of ENT Surgeons (BV-HNO), the Professional Federation of Paediatricians and Youth Doctors (BVKJ), the Federal Association of Pulmonologists (BDP) and the German Dermatologists Association (BVDD). Allergo J Int. 2014;23:282-318.

236. Kleine-Tebbe J, Bufe A, Ebner C, Eigenmann P, Friedrichs F, Fuchs T, et al. Die spezifische Immuntherapie (Hyposensibilisierung) bei IgE-vermittelten allergischen Erkrankungen. Leitlinie der Deutschen Gesellschaft für Allergologie und klinische Immunologie (DGAKI), des Ärzteverbandes Deutscher Allergologen (ÄDA), der Gesellschaft für Pädiatrische Allergologie und Umweltmedizin (GPA), der Österreichischen Gesellschaft für Allergologie und Immunologie (ÖGAI) und der Schweizerischen Gesellschaft für Allergologie und Immunologie (SGAI). Allergo J. 2009;18:508-37.

237. Kuna P, Kaczmarek J, Kupczyk MJ. Efficacy and safety of immunotherapy for allergies to Alternaria alternata in children. JAllergy Clin Immunol. 2011;127:502-8.
238. Infectious Diseases Working Party (AGIHO) of the German Society of Hematology and Oncology (DGHO), Böhme A, Ruhnke M, Buchheidt D, Cornely OA, Einsele H, Enzensberger R, et al. Treatment of invasive fungal infections in cancer patients - Recommendations of the Infectious Diseases Working Party (AGIHO) of the German Society of Hematology and Oncology (DGHO). Ann Hematol. 2009;88:97-110.

239. Cornely OA, Böhme A, Buchheidt D, Einsele H, Heinz WJ, Karthaus M, et al. Primary prophylaxis of invasive fungal Infections in patients with hematologic malignancies. Recommendations of the Infectious Diseases Working Party of the German Society for Haematology and Oncology. Haematologica. 2009;94:113-22.

240. Rocchi S, Reboux G, Larosa F, Scherer E, Daguindeau E, Berceanu A, et al. Evaluation of invasive aspergillosis risk of immunocompromised patients alternatively hospitalized in hematology intensive care unit and at home. Indoor Air. 2014;24:652-61.

241. Rao D, Phipatanakul W. Impact of environmental controls on childhood asthma. Curr Allergy Asthma Rep. 2011;11:414-20. 